\title{
SEMIANNUAL REPORT 1995
}

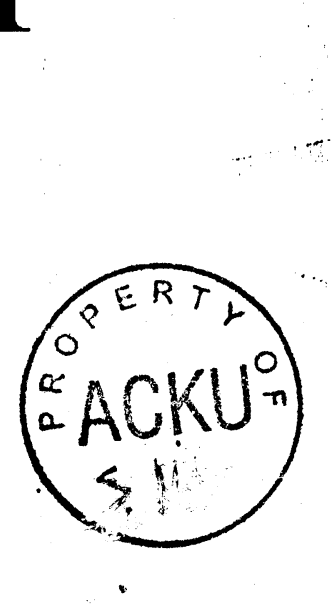

NORWEGIAN PROJECT OFFICE Rural Rehabilitation Association for Afghanistan (NPO/RRAA)

15-B OLD JAMRUD ROAD; UNIVERSITY TOWN; PESHAWAR TEL: 41129 / 45210 


\section{CONTENIS}

TITLE

PAGE

SUMMARY \& BACKGROUND

IMPLEMENTATION POLICIES

- PARTICIPATORY ASSESSMENT OF NEEDS (PAN)

ORGANIZATIONAL STRUCRURE

RECRUITMENT POLICY \& STAFHING

PROBLEMS

FUNDING SOURCES

ACTIVITIES \& ACHEVEMENTS:

A. AFGHANISTAN PROGRAMS:

Gardiz Regional Office

Herat Regional Office

Jalalabab Regioinal Office

Mazar Regional Office

B. PAKISTAN PROGRAMS:

Income Generation Program, Female

FINANCIAL SUMMARY 


\section{SUMMARY \& BACKGROUND}

The Norwegian Project Office (NPO) was established at the beginning of the year 1990 through taking over some projects previously, since 1984, implemented by Austrian Relief Committee (ARC). Income generation formed the nature of these projects, which targeted the most vulnerable groups of the Afghan communities, both, in Pakistan and Afghanistan. These groups included, but were not limited to, the disabled, needy widows and female-headed households.

Because of the massive repatriations of the refugees in 1992, NPO transferred or expanded most projects into the country in 1993. Only a limited number of the projects remained in Pakistan to serve the neediest refugees. Committed to the concept of equitable distribution of resources, NPO created four regional offices in four different zones of the country, i.e., in South-East, East, South, and North. The regional offices are located in the following cities and are called by the name of those cities:

Jalalabad, Gardiz, Herat; Mazar

These regional offices carry out programs in the following eight provinces:

$\begin{array}{ll}\text { Nangarhar } & \text { Laghman } \\ \text { Paktia } & \text { Paktika } \\ \text { Herat } & \text { Balkh } \\ \text { Baghlan } & \text { Khost }\end{array}$

Since its foundation, NPO was associated with and supervised by Norwegian Church Aid/Norwegian Refugee Council (NCA/NRC). At the outset of 1994, however, NPO was changed to an Afghan NGO with' the new name of Rural Rehabilitation Association for Afghanistan (RRAA). The orgänization in its Central Administration (CA) meeting in September 1994 modified the name to "Norwegian Project Office/Rural Rehabilitation Association for Afghanistan" (NPO/RRAA). Despite remaining the major funding source of NPO/RRAA, NCA/NRC does not play the previous supervisory role for NPO/RRAA.

Two chief factors, on the part of NPO/RRAA, contributed to the creation of a challenging atmosphere of work inside the country:

(1) new independent status

(2) expanded operations inside Afghanistan

The above mentioned factors somewhat coincided and intertwined with each other. NPO/RRAA started its expánsion inside the country from the beginning of the year 1993 while it became an independent Afghan NGO in January 1994.

Further challenges were added to this atmosphere by the adoption of some new poilicies related to community contribution \& community participation, and by the existence of the prevailing socio-political uncertainty and instability in the country. NPO/RRAA was to deal with the impacts of these factors and plan for their probable outcomes. 
Consequently, there was a need for a flexible organization with the highest amount of input from its own members, associates, and recipients of its services to encounter the unpredictable working environment inside the country. To achieve this, NPO/RRAA underwent a process of re-organization. The resulted new structure (discussed briefly under a separate heading in this report; for details see the NPO/RRAA's "Policy guidelines" and "Rules \& Regulations", 1995) helped NPO/RRAA to mobilize its human resources and managerial capabilities. The Central Office, on one hand, delegated greater decision-making power to the regional offices and tried to incorporate in its plans as much of their suggestions \& recommendations as possible. On the other hand, the Central Office increased its supervisory role through frequent dispatch of monitoring teams to the regions. The ultimate goal has been to enhance the "give" and "take" process between the center and the peripheries, to fill the gap between them, and to reach the unity of plan and practice.

The implementation policies revolve around the principal theme of integrated rural rehabilitation/development. Community participation, community contribution, targeting the neediest groups of the community, no-free-assistance, cooperation \& coordination with local authorities, related NGO's, and UN agencies in projects implementation are some concrete implementation policies. NPO/RRAA's policies and projects are'considered as means to achieve the following long and short term objectives:

- encourage repatriation of external \& internal refugees;

- prevent urbanization;

- support vulnerable families \& groups regardless of sex and ethnic background;

- contribute toward rehabilitation and development of the rural areas;

- provide opportunities for the return of a normal life to have an impact on the restoration of peace and tranquility

Determined to achieve these goals, NPO/RRAA executed an array of projects in Pakistan and Afghanistan. The projects implemented in Pakistan included:

\section{- Income generation for women}

\section{- Income generation for the disabled}

\section{- Loan Scheme for Female}

Providing training, tool kits, and small loans (only for women) for the disabled, poor widows, needy women, and the new arrivals from Kabul being the main functions of these projects, they were designed to enable these refugees to produce an income and to transfer the skills and the tool-kits to the country upon their return to Afghanistan. Relative certainty prevailed the work environment in Pakistan. Achievements : of the projects were more or less as prospected. However, the organization performed in a different atmosphere inside Afghanistan.

Besides pursuing the former activity lines such as income generation and construction, Afghanistan programs embodied an extra component of community rehabilitation to respond 
to the vital needs of local people in repairing the damages of the war. Community rehabilitation included:

- road rehabilitation

- shelter

- community support

- poultry

- veterinary

- agriculture

- horticulture

- irrigation

- water supply

Steady progress characterized the project activities, although, instability and uncertainty predominated the operative environment inside the country. The continuing war in Afghanistan: caused countless problems and obstacles for the projects inside the country. Lack of security, impaired transportation and communication systems, financial fluctuations, collapse of banking systems, and the like adverse factors acted against NPO/RRAA's plans and calculations. In addition, an internal obstacle was unfamiliarity of some of NPO/RRAA's staff members with the new implementation policies. Nonetheless, the organization learned the art of survival and progress in an unstable and hostile environment.

NPO/RRAA operated with an annual budget of over 51 million Pak. rupees and a total number of 251 employees. 82.4\% of the staff were based in Afghanistan. Funds were made available by NCA/NRC, NORAD, UNHCR, IRC/RAP, and, in kind, by WFP and local communities. Over $81 \%$ of the funds was allocated to Afghanistan and about $8.8 \%$ to Pakistan operations.

NPO/RRAA, alongside these organizational improvements, set some new implementation policies to serve as action guides for, both, the Pakistan and cross-border programs. The forthcoming pages are allocated to the following headings:

* Implementation Policies

* Participatory Assessment of Needs (PAN)

* Organizational Structure

* $\quad$ Recruitment policies \& Staffing

* Problems

* $\quad$ Funding Sources

\section{MMPLEMENTATION POLICIES}

As the name of the organization suggests, rehabilitation and sustainable development of the rural areas form the principal goal of the organization. To ensure achievement of this goal, NPO/RRAA formulated a set of integrated implementation policies: The following are some leading policy points:

* Community Contribution

* Community Participation

* $\quad$ No Free Distribution/Services

* Cooperation \& Coordination with local authorities, NGO's, \& UN agencies in projects implementation 
The new policies, particularly the top two, community contribution and community participation, NPO/RRAA believes, encourage interactions between the community and the implementing agency in the reconstructing and independent developing, of $\mathrm{the} r \mathrm{ral}$ communities. Although NPO/RRAA does not offer free assistance, it does, however, incur part of the costs $(30 \%$ $50 \%$ ) of the assistance provided for the participants.

It is expected that in the short run, the new policies should contribute to the repatriation of external and internal refugees and restoration of peace and tranquility in

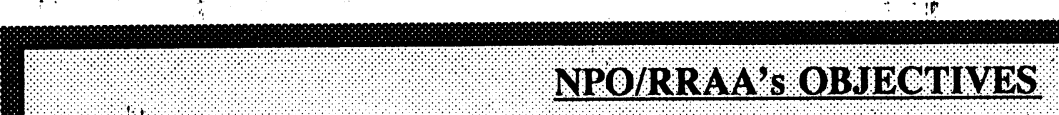

NPO/RRAA has been striving to achieve the following short-term and long-term objectives:

* Encourage repatriation of external and internal refugees

* Prevent urbanization

* Support vulnerable families \& groups irrespective of their sex and ethnic background

* Contribute toward rehabilitation \& development of rural areas

* Provide opportunities for the return of a normal life to have an impact on the restoration of peace and tranquility

Afghanistan.

Despite all its preparations and planing, NPO/RRAA was not immune to the unfavorable influences of the prevailing uncertain and unstable situation in Afghanistan. NPO/RRAA worked in a war-torn country where the country has politically been divided, inflation is galloping, and the war is destroying and burning the human lives, infrastructures, wealth and properties of its populace. This situation led to creation of numerous problems for NGO's working inside Afghanistan; this report is not apt to elaborating on them. To speak of some major problems, caused by the war state for NPO/RRAA, one can point to lack of personnel and property security, communication and transportation obstacles, financial fluctuations, and lack of banking system.

In terms of policy implementation, community participation has been the main focus of NPO/RRAA in 1995. In line with this orientation, a new task, called Participatory Assessment of Needs (PAN), was undertaken in the beginning of the current year.

\section{PARTICIPATORY ASSESSMENT OF NEEDS (PAN)}

During its 5 th round of CA meetings in January 1995, NPO/RRAA concluded that its project proposals for the year 1996 and the years to come should draw their justification from data collected through a special effort carried out jointly by NPO/RRAA's field staff and the community folks. This venture, called Participatory Assessment of Needs (PAN), was based on this assumption to provide greater role for the community people in identifying their needs 
and problems, and in designing and implementing the projects in respond to those needs and problems. In the work plan of.PAN the objectives of the task were stated as the following:

To Plan and manage the projects on a more realistic basis

To have local people take more active part in the rehabilitating and developing activities/projects

To mobilize the human and material resources of local communities

To decrease dependency of the local communities on outsiders

To get deeper insight of the condition of affairs in the villages

A team of five consultahts developed a guideline for the implementation of PAN in the four working regions, Gardiz, Herat,

Jalalabad, and Mazar, in the month of March. In the third week of March, a team, under the guidance of one consultant, was formed in each regional office to carry out PAN. Effort was made to choose the team members from various disciplines of work, i.e., engineering, agriculture, Income generation, and so on. Both men and women were included in the teams, except for Gardiz region where women could not participate as the Taliban's policy about women workers wa's not Known then. Actual field work of PAN took 5-6 weeks. Three to four districts, in each region was studied and pertinent data was collected. In the month of October the report on PAN will be completed and published. Almost all project proposed to the donors for the year 1996 and the years to come are those ones that were jointly identified by the local people and the PAN teams.

\section{ORGANIZATIONAL STRUCTURE}

The organization consists mainly of one Central Office (C.O.) and four Regional Offices (R.O.). Currently the Central Office is based in Peshawar. When the security situation turns into normal and the governmental departments and other institutions such as banks, UN agencies, etc. become functional it will be moved to the capital of Afghanistan. The C.O. is the Head Office of the organization that plays the central role in coordination, supervision, general policy formulation, documentation, and fund raising.

The four Regional Offices, directly linked to and supervised by the Central Office, are responsible for implementation of the projects. The Regional Offices are in Jalalabad, Mazar, Herat, and Gardiz Cities.

Within the organization there are some other arrangements that carry out the planning and decision-making jobs: At the central level there are Central Administration (CA) and Central Coordination Group (CCG). At the regional level, however, there are Regional Coordination Groups (RCG).

The Central Administration (CA), consisted of the Regional Managers, Chief Admin. Manager, and Program Consultants, under the leadership of the director, forms the leadership team of 
the Organization. Mainly dealing-with policy matters, CA, under normal conditions, meets four times a year (every three months). CA is responsible for formulating new policies and annual proposals.

Central Coordination Group (CCG) contains the Chief Admin. Manager, Accounts Manager, and the Consultants under the leadership of the Director. It has weekly meetings at the Central Office to update the information and coordinate general activities. In addition, all urgent policy issues including proposals that cannot be put-off for the CA meetings, are also discussed at these meetings.

Program Managers, Admin. Manager, and Accountant, under the leadership of the Regional Manager, form the Regional Coordination Group (RCG). RCG has weekly meetings whose chief purpose is to update the information and coordinate activities of different programs. Additionally, the meetings deal with and make decisions on specific policy matters, within the framework of general pólicies, and major management issues.

At the highest level of the organization there is a body called Advisory Board (AB). It is designed to assume an advisory role related to general policies and proposals, and assessment of NPO/RRAA's activities in terms of the fund raising matters. Besides these advisory roles, the Board recruits the Director of NPO/RRAA. The Board is formed of seven qualified persons, two from inside the organization and five from outside. The first $A B$ was formed in September 1994. Under normal conditions the Advisory Board meets twice a year.

\section{RECRUITMENT POLICIES AND STAFFING}

A total of 251 employees support NPO/RRAA activities. Out of this total, 207 persons (82\%) work inside the country and the remaining 44 persons (18\%) work in Pakistan: The latter figure includes program support staff (15 members of the Central Office) whose service are evenly extended to both-Pakistan and Afghanistan programs.

NPO/RRAA is committed to fairness, efficiency, and development of human resources in its recruitment practices. It tries to mirror the ethnic, gender, and religious composition of the society in its organizational structure. All job vacancies are internally and externally announced. Job descriptions for all positions have been prepared and accommodated in the "Employees Handbook".

Cross border staff are restrictively hired from the field. Two major reasons for this policy point are to prevent problems occurring: with Pakistan-based employees in terms of travelling for family visits, and to contribute to human resources development inside the country.

\section{PROBLEMS}

The problems encountered during the last six months were mainly associated with activities inside the country. Pakistan-based projects did not experience any major problem during this period. In the beginning of January, a double-cab Toyota pickup of the central office was stolen by some people inside the Peshawar city. 
Problems experienced by the cross-border programs, fall in the following six groups:

1. Lack of Security

2. Political instability and disunity

3. Collapse of Communication systems

4. Transportation and Travelling barriers

5. Financial Problems such as inflation, lack of banking system, price hike, etc.

6. Unavailability of some raw materials, and other needed items

Besides these general and persistent obstacles, though related to them, there were some specific problems encountered particularly by Gardiz and Jalalabad programs. These incidents were connected to the activities of the female programs both in Gardiz and Jalalabad, and security in Jalalabad.

\section{FEMALE ACTIVITIES:}

After Taliban assumed power in Gardiz, the regional office stopped female program activities to get an official permission from the new authorities. This process, due to the disorderly organization of the new rulers, took several months. It was only in June that an agreement was signed between the GRO and the Taliban to allow the female program activities.

On May 28, the Nangarhar Jehadi Council issued an order to disallow female work in all aid agencies working in Nangarhar and Laghman. ACBAR, on behalf of the aid agencies is in contact with the Jehadi Council to solve the problem. According to the recent reports, some progress has been made towards the solution of the issue.

\section{VEHICLE HIJACK \& OFFICE BÜRGLARY IN JALALABAD:}

Some unknown, armed people broke into the regional office on 15/16 June, 1995 and took away some cash and non-cash property of the office. No clue has so far been found about the burglars. In another incident, a double cabin Toyota pickup of JRO on its way from Jalalabad to Laghman was hijacked by some armed men, on 28/6/95 at 3:30 pm near Jalalabad University. Seärch operations through both, official and non-official channels have been launched with no clue as yet found.

\section{FUNDING SOURCES}

NPO/RRAA's achievements were made possible through contribution of several organizations and communities. Funds were made available by NCA/NRC, NORAD, UNHCR, IRC/RAP, and , in kind, by WFP and communities.

NCA/NRC remained the major funding source of NPO/RRAA (For details of funding refer to the Financial Summary Report). 


\section{GARDIZ REGIONAL OFFICE}

\section{POLITICAL \& SECURITY SITUATION:}

The Taliban, who took over the power in April 1995 in both paktia and paktika are still controlling the area. At the beginning, they were warmly welcomed by the local people, however, as the time went by the people's instantaneous enthusiasm gradually diminished One reason was the appoitment of non-local people to the key positions such as the governer, and heads of army and civilian departments. Meanwhile, some of the former, infamous local commonders joined the Taliban forces which caused resntment of the local people and tribe elders.

Despite these, the security of the cities, roads, and localities improved under the leadership of Taliban. NPO/RRAA Gardiz and other NGO's working in the area enjoyed a safe and secure working environmet in the first six months of 1995. The Taliban authorities extended their good will and 'interest in the work of NGO's, and are doing their best to assist the NGO's to carry out their activities without any problem.

\section{PROGRAMS \& PROJECTS ACHIEVEMENTS:}

The regional office in Gardiz is implementing the following programs and Projects:

1. Female Income Generation (I/G) Program

2. Disabled male Income Generation Project

3. Technical Training Center Program

4. Shelter Project

5. Horticulture Project

6. Veterinary Clinics

7. Tree Plantation Project

8. Energy Production Project

\section{INCOME GENERETION PROGRAM FOR FEMALE:}

Once the Taliban assumed power in the beginnning of the year, continuationi of the female program became a question for the GRO. The office in Gardiz had to get an official approval for the female porgram from the new authorities. After extended talks and discussions, it was only in June 1995 that the Gardiz office was able to sign an agreement with the localauthorities in Gardiz that allowed activiity of the female program. During this time the office sent its female staff to Peshawar to attend some training courses.

The female program consists of three different projects:

\section{Nursery Project}

2. poultry farms

3. Individual Cases

Surveys were carried out in Colalgo, chawni, rubat and tera villages and 50 needy and poor widows, 25 Pushtoon, 15 Tajik and 10 Shiat-Hazara, were identified as eligible persons to be assisted. Very soon, 20 widows from among them will be given seeds, fertilizer, and tools to establish small tree nurseries inside their houses. The saplings produced will be

NPO/RRAA, Semiannual Report 1995 
purchased from the participants, each for Rs.2, that will create an income of Rs.3,000-4,000 for each participant during the year. Another 20 widows will be given chicks under the poultry farms project who are expected to produce an income of Rs.30 per day from sale of eggs. Another 30 widows will be assisted with tools and/or training to either utilize their present skills, or learn new skills and earn incomes. It is expected that, in average, they will have an income of Rs.1,000 per month. It is expected that the implementation of the mentioned projects will help the participants to take active part in the socio-economic network of their respective communities which: will improve their social status and lead to their independence and prosperity. Income generated from the repayment of last year's loans was Rs. 19,188 . Expenditures of the program in the last six months made $19 \%$ of the actual budget.

\section{INCOME GENERATION PROJET FOR DISABLED:}

The project is to train at least 25 needy disabled men in Paktika, Paktia and Khost provinces.

A tailoring course for 10 Pushtoon disabled was established on 11.6.1995 in Tani district. The trainees were identified from among the poorest disabled in Narizi, Daragi, Landay and Sanaki villages. The course will run.for six months. A poultry training course was established at the TTC Gardiz on 1,7.95 for five disabled men from Chawni, Rubat and Colalgo villages of Zurmat district which will be completed in one month. Regular monitoring of the progress of the courses have been carried out. The graduates will be assisted with tools and equipment of their learned skills on a subsidized loan basis to utilize their skills. Agreements have been singed with the trainees who would pay $50 \%$ of the costs of tools and equipment. The expecte impact of the project will be an average daily income of Rs. 30 for the participants and assisting the participants to become active and respected members of their respective communities. The project had an income of Rs.1,580. Expenditures of the program in the last six months made $22.6 \%$ of the actual budget.

\section{TECHNICAL TRAINING CENTER:}

Under this program 40 persons including 10 disabled men will be offered training and tools and equipment of their skills. The tools and equipment are given on a subsidized loan basis to be repaid in small instalments within a period of 12 months.

After surveys of different villages of Zurmat, Zadran and Said Karam districts, carried out from first to 13 April 1995, 25 needy and poor young persons whose ages were between 16-26; were identified for training at the TTC in Gardiz. Ethnic composition of the participants shows $40 \%$ Tajiks, $40 \%$ Pushtoons, and $20 \%$ Hazara-Shiats. 'The skills, including masonry, tinsmithry, and carpentry, have been choosen according to the needs of the communities and the practising ability of the trainees. The center started its training activities on 26.3.1995 with 21 trainees. Since the trainees are selected from the rural areas the center has established a dormitory for its trainees; as well.

A poultry training course for 10 disabled was established on 1.7.1995 at the center of TTC and the trainees for the course were selected from the rural areas of Zurmat, Zadran and said Karam. The trainees belong to Pushtoon and Tajik ethnic groups, and to Sunni and Shaya denominations. Out of the total number, 5 belong to the $I / G$ Disabled male program that was metioned under activities of that "program.

NPO/RRAA, Somiannual Roport 1995 
Agreements have been singed with all trainees according to which the graduates will receive to ols and equpment of their related skills at $50 \%$ subsidized prices. An average daily income

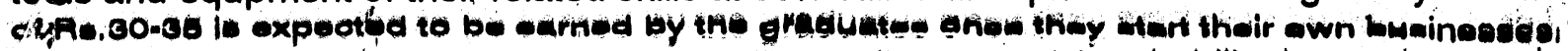
Wis, as well, expected that the graduates will contribute towards rehabilltation and peace in "their respective communities. Income from the repayment of last year's loans amounted to Rs. 29,672 . Expenditures of the program in the last six months made $30.6 \%$ of the actual budget.

\section{SHELTER PROJECT:}

Reinforced concrete roofing materials were distributed to 67 repatriated families in Khost at a subsidized price, $50 \%$ of the materials costs. The participants, of the project, all Pushtoons, were identified from among the poorest families in Konday, Matoon, Sabaray and Mandozay. villages.

In Urgoon, due to the insufficient number of returnees and little house construction work in the area, the project was only able to distribute roofing materials to 7 families. Therefore, it was decided to decrease the production capacity in 'Urgoon and increase it in Khost.

Follow up and monitoring during and after the installation was carried out in order to make sure that the safety requirement's were met. By the end of 1995, 340 needy returned, refugee families in Khost and Urgoon .will be assisted in the rehabilitation of their houses. The expected impacts of the project are facilitating and encouraging repatriation of Afghan refugees, rehabilitation of normal life in the villages, and preserving the forests. $90 \%$ of the participants belong to Pushtoon and the rest are Tajik. Total community contribution for the reporting period was Rs.225,100, which constituted $35.6 \%$ of the original plan. Expenditures: of the program in the last six months made $47 \%$ of the actual budget.

\section{HORTICULTURE}

The project started its activities on 1 March, 1995. A total of 8,200 fruit trees, property of 92 farmers from Banyan, Doghabad, Neeknam, Khataba villages of Gardiz, and Dowlay way; Matoon, Mandozay and Fakiran villages of Khost were sprayed against Green Aphids, Small Crminmoth and Black Aphids diseases. The participants of the project were selected from among the poorest farmers. The participants paid $70 \%$ of

the medicine costs. The program had an income of Rs.16,125 from its spraying activities which was $20 \%$ of -the planned community contribution. Groups of 5-7 farmers have participated in the process of spraying and group training. Expenditures of the program in the last six months made $38.6 \%$ of the actual budget.

Twenty small nurseries, established on the land of farmers in Gardiz and Zurmat in 1993 and 1994, were monitored.

\section{VETERINARY CLINICS}

A total of 380 animals such as cows, sheep, goats and chicks were treated or vaccinateg against F.M.D, anthrax, mastitis and pneamonis diseases. The animals treated belonged to 142 farmers and nomads members of Pushtoon \& Tajik ethnic groups from Matoon, Manghas villages of Khost, and from Tera, Kataba and Alishir villages of Gardiz. In Khost, $90 \%$ of the beneficiaries were Pushtoon, while the remaining $10 \%$ were Tajiks; however, in Paktia, $50 \%$ Pushtoon, $30 \%$ ' Tajik, and $20 \%$ nomads composed the program participants. The 
Medicine cost was fully contributed by the farmers and nomads. The cilinics had a total income of Rs. 20,105 which made up $25 \%$ of the planned community contribution. During regular visits of the clinic staff to the field, 110 farmers and nomads, in groups of $10-12$, were trained in the field of animal husbandry. The expected impacts of the project is reduction of animal diseases, higher awareness of the prevention of animal diseases, and decrease in the morbidity and mortality rate of animal diseases. Expenditures of the program in the last six. months made $26 \%$ of the actual budget.

\section{TREE PLANTATION PROJECT}

In order to prevent pollution and soil erosion seeds for production of 100,000 saplings were planted in the plastic bags in the office compound of GRO in Khost. The saplings will be shifted to Gardiz in October 95 to be planted in different areas of Gardiz.

With close cooperation of the local authorities, a total of 2,900 young ornamental trees were also planted on the both sides of the city road in Gardiz city. The expected impact of this project will be creation of a healthy living environment, and protection of the thin tayer of soil on the hills around the Gardiz Town. Expenditures of the program in the last six months made $22 \%$ of the actual budḡet.

\section{ENERGY PRODUCTION PROJECT}

The project was designed to produce fuel gas from the manuer of livestock at the single houshold level. The first sample was produced at the Khost office of GRO which now provides gas for the cooking and heating purposes of the office. In order to identify the participants for the project a survey was carried out in Ali sheer, Mandozay, Matoon and Sabaray villages of Khost and 30 . families that belonged to Pushtoon ethnic group were selected to be assisted by the project. The project has already started producing the sylinders which will be distributed among the families in the second half of the year. The expected impact of the project will be a recuction on the consumption of fuel wood, and economic improvement of the target families. Expenditures of the program in the last six months made $12.4 \%$ of the actual budget.

\section{PROBLEMS AND SOLUTIONS:}

The female projects were delayed due to the unclear policy of the Taliban about women's work outside their houses. An agreement, however, was signed with the local authorities in June that led to the continuation of the female projects.

- Due to the low return level of the refugees and the low level of the house building work in Urgoon, the program was only able to distribute roofing materials to 7 families. It was decided, hence, to reduce production of roofing materials in Urgoon and increase it in Khost. 


\section{HERAT REGIONAL OFFICE}

Herat province is located in the West part of Afghanistan, about 1,140 km from the capital, Kabul. Herat province has borders with Iran on the West and with Trukmanistan on the North.

In pre-war situation, Herat province, with its 12 districts and 2 sub-districts, had a population of around 623,000 . During the war, Herat province sustained great damages in terms of both, human and material resources. Thousands of people were killed, and many others were left crippled. The houses were destroyed, irrigation systems were demolished, and thousands Jeribs of land were-left uncultivated. Many families took refuge in Iran and other safe places.

In the post-war situation, however, owing to the repatriation of Heratis and other Afghans from Iran, and the influx of Kabuli displaced families, around one million people are living in this: province. More people are expected to return from Iran in the current year. The province., which has 14 districts now, presents a coexistence of various ethnic groups such as Tajiks, Pashtoons, Turkamans, and Uzbaks with a majority of Tajiks and a minority of Uzbaks. Presently, most of the people who migrated, have returned home and they have numerous problems regarding shelter, job, food stuff, drinking water and health services, a'griculture, etc. that cannot be solved without outside support. Therefore NPO/RRAA established its office in Herat, in 1993. During 1993 and 1994 some programs such as, schools and clinics construction, Income Generation, Agriculture, Road Rehabilitation, TTC and Relief were implemented. In 1995, the NPO/RRAA Herat, with a total budget of Rs. $11,457,000$ and 53 staff members, implements the following programs:

1. Agriculture program

2. Technical Training Center

3. Road Rehabilitation program

4. Vocational Training program for female

5. Vocational Training program for disabled male

6. Construction program

7. Shelter program

8. Relief program

\section{AGRICULTURE PROGRAM}

The program activities during the last six months were focused on Aurdu Khan Nusrery Farm. Located in Aurdu khan village of Engil district, $15 \mathrm{~km}$ to the east of Herat city, this farm was developed in an area of 15 Jeribs (= 3 hectares)in 1993. The farm whose land was contributed by the government, produces seedlings of fruit trees. Various fruit trees such as almond, apricot, and nuts have been planted of which the first batch will be distributed in the next spring. The seedlings and seeds produced in the farm will be given to the farmers at subsidized prices. Priority will be given to the most vulnerable farmers. Twenty farmers were employed as short term employees to look after the farm. The following activities were carried. out by these farmer's in the nu'rsery farm: Leveling of the land, cleaning of the irrigation ditches, planting of some varieties of fruit trees, fertilizing, cultivating, weeding, irrigating and spraying of the nursery farm trees. 
Young fruit trees from Nursery Farm will be sold to the vulnerable farmers in villages at a subsidized price. Training, assistance and regular advice will be offered by the project staff to the farmers to established and run the scheme. Prior to implementation of the project agreements will be signed with local authorities and individual farmers.

Following a proposal for food stuff, NPO/RRAA Herat has received wheat, cooking oil and sugar for its Nursery farm workers as a monthly ration, since April 1995 and will be receiving it up to the end of Dec. 1995.

In the nursery farm, ornamental and fruits seeds such as apricot, almond, walnut, mulberry and ash, have been planted in 12 Jeribs of land.

The plants will be delivered to the public gardens, schools, hospitals, margins of the main roads, etc. The table exhibits information about the activities of the farm in terms of type of trees planted, planting dates, and the number of various trees planted:

\begin{tabular}{|c|c|c|c|}
\hline Type of Trees & $\begin{array}{l}\text { Planting } \\
\text { Date }\end{array}$ & Total plants & Distribution Date \\
\hline Apricot & Dec.93 & 11,988 & March 96 \\
\hline Almond & Dec.93 & 41,990 & March 96 \\
\hline Walnut & Dec.93 & 16,000 & March 96 \\
\hline Mulberry & Dec.93 & 59,994 & March 96 \\
\hline Apricot & Jan.95 & 28,000 & March 98 \\
\hline Almond & Jan.95 & 22,400 & March 98 \\
\hline Walnut & Jan.95 & 16,000 & March 98 \\
\hline Mulberry & Mar.95 & 50,000 & March 98 \\
\hline Ash & Dec. 93 & 30,000 & Mar.96 \\
\hline Ash & Mar.95 & 3,500 & Mar.98 \\
\hline $\begin{array}{lllll} & 0 & t & a & 1\end{array}$ & & 279,872 & \\
\hline
\end{tabular}

Presently, there are a total of 279,872 young trees in an area of 42 Jeribs of land in Urdu Khan nursery farm., The project's impact will be a better natural environment, increased fruit production, and greenery of the area. The program expenses in the past six months constituted $10.8 \%$ * of the actual budget.

\section{TECHNICAL TRAINING CENTER AND HOSTEL FOR DISABLED (TTC):}

On 30 November 1993, a contract was signed between NCA/NRC and UNHCR Tehran that a group of 50 disabled returnees should be trained in various proper skills at a training center in Herat city. Consequently, on first Jan. 1994, Herat Technical Training Center and Hostel for

*. Due to some transportation obstacles, the acounts office in the central ofice did not receive some of the expenditure documents from Herat so, the figures reflected on the current report do not match the aqtual expenses of Herat programs. 
disabled (TTC) was estäblished to train disabled returnees. Literacy courses were part of the plan.

According to the contract, 50 disabled had to be returned, while only a group of 9 disabled returnees arrived in May 1994, and received training in tailoring skill. After completion of the course the graduates were sent to their respective origins.

In 1995, it was expected that the center would receive 50 disabled returnees from Iran but UNHCR Tehran could not send any disabled to the center. Hence, in consultation with NCA/NRC, the NPO/RRAA Herat office decided to recruit and train 100 disabled men from the nearby villages and districts. The project has been implemented in cooperation with the Disabled and Martyręd Department (Governmental Organization) of Herat province. Although the center is located in the center of Herat, the disabled men have been identified and selected from villages of different villages and districts.

\section{Activities:}

During the past six months, TTC has been offering training in different skills such as radio repairing, shoe making, tailoring, and watch repairing for 36 vulnerable disabled men. Duration of the courses is six months, except for the shoe making course ( 8 months), five days a week and 8 hours in a day.

The following table shows the length of the courses, number of trainees and trainers:

\begin{tabular}{|c|c|c|c|c|c|c|}
\hline No & $\begin{array}{l}\text { Course } \\
\text { Name }\end{array}$ & $\begin{array}{l}\text { Course } \\
\text { Cength }\end{array}$ & $\begin{array}{l}\text { Starting } \\
\text { Date }\end{array}$ & $\begin{array}{l}\text { Ending } \\
\text { Date }\end{array}$ & $\begin{array}{l}\text { No. of } \\
\text { Traineess }\end{array}$ & $\begin{array}{l}\text { No. of } \\
\text { Trainers }\end{array}$ \\
\hline 1 & $\begin{array}{l}\text { Radio } \\
\text { Repairing }\end{array}$ & Six months & 10.4 .95 & 10.11 .95 & 10 & 1 \\
\hline 2 & Shoe making & $\begin{array}{l}\text { Eight } \\
\text { months. }\end{array}$ & 2.5 .95 & $\begin{array}{l}2.12 .95 \\
\therefore \\
\end{array}$ & 10 & 2 \\
\hline 3 & Tailoring & Six months & 21.6 .95 & 21.12 .95 & 10 & 1 \\
\hline 4 & Watch Repairing & Six months & 28.6 .95 & 12.28 .95 & 6 & 1 \\
\hline & Total & & & & & 5 \\
\hline
\end{tabular}

Literacy classes are part of the curriculum so, the trainees are taught how to read and write, as well. Health care is also provided for the trainees. TTC has a good coordination with ICRC, and Red Crescent Society regarding maintenance and renewal of artificial limbs. The program expenses in the past six months constituted $2.4 \%$ of the actual budget.

\section{ROAD REHABILITATION PROGRAM:}

In 1995, 37 culverts were going to be built in Bushron and Sofian villages ö Enjil district. 23,328 people, members of 2,916 families and residents of 17 villages, will use these culverts.

30 culverts that serve 12,000 residents of the following nine villages, were constructed: Bushran, Al,wand, Moqueem Abad, Rexeshk, Saleh Abad, Rabat Kashmir, Beshai Mukhtar, Asiaqul, and Jahferabad. 
The department of rural development (Governmental Organization) was encouraged to take on the graveling and repairing of the roads on which the culverts were made. As a result, $5 \mathrm{~km}$ road was repaired and graveled.

Community contribution for this project amounted to Rs. 47,000. The following table shows details of the community share. The share of the government has not been. reflected in this table:

\begin{tabular}{|c|c|c|c|}
\hline No, & Typo of Activities & Wage Per M3 & Total value \\
\hline 1 & Excavation $413,5 \mathrm{M}^{\prime}$ & 1,500 Afs. & 620,250 Afs. \\
\hline 2 & Transfer of sand $240 \mathrm{M3}$ & 10,000 Afs. & $2,400,000$ Afs. \\
\hline 3 & Stone work 105 M3 & 8,000 Afs. & 840,000 Afs. \\
\hline 4 & Molding 200 slabs & 3,000 Afs. & 600,000 Afs. \\
\hline 5 & $\begin{array}{l}\text { Protective walls on the both sides of culverts, } 30 \\
\text { culverts }\end{array}$ & 9,050 Afs. & 271,500 Afs. \\
\hline & Cotal Community contribution & & $4,731,750$ Afs \\
\hline
\end{tabular}

Actual community contribution made up $19.5 \%$ of the original plan.

\section{Future Work Plan:}

The work of 7 culverts will start veny soon in Sofian villages of Enjil district which is located $17 \mathrm{~km}$ to the west of Herat city. These culverts will be completed by the end of Aügust 1995. The program expenses in the past six months constituted $20.4 \%$ of the actual budget.

\section{VOCATIONAL TRAINING PROGRAM FOR WOMEN:}

A survey was conducted at the beginning of 1995 in Charbagh Ferozah, and Rabat Turkha villages of Enjil and Karukh districts, as a result of which, 30 vulnerable women were selected to be trained in vocational courses. The following three courses were established in the April 1995:

\begin{tabular}{|c|c|c|c|c|c|c|}
\hline \multirow[t]{2}{*}{ No. } & \multirow[t]{2}{*}{ Course title } & \multicolumn{2}{|l|}{ ४०० } & \multirow{2}{*}{ No. } & \multirow{2}{*}{ started } & \multirow{2}{*}{ buration } \\
\hline & & village & District & & & \\
\hline 1 & Carpet weaving & Rabat Turkha & Enjil & 10 & $19 / 4$ & 6 months \\
\hline 2 & Embroidery & Charbagh Feroza & Enjil & 10 & $30 / 4$ & 4 months \\
\hline 3 & Carpet weaving & Karukh center & Karukh & 10 & $30 / 4$ & 6 months \\
\hline & O T A L : & , & & 30 & & \\
\hline
\end{tabular}

Then, another survey was carried out in various villages of Kushk district in June 1995. Out. of 210 women interviewed, 70 women were selected who were composed of widows and women with disabled husbands. The following table shows the selected mobile vocational training courses which have already been identified and will be started in July: 


\begin{tabular}{|c|c|c|c|c|c|c|c|}
\hline \multirow[t]{2}{*}{ TYPE OF COURSE } & \multirow{2}{*}{ SURVEY } & \multicolumn{2}{|l|}{ LOCATION } & \multirow{2}{*}{ COUASE } & \multicolumn{3}{|c|}{ NO OF PARTICIPANTS } \\
\hline & & YILAGE & $0 \mid s T$ & & $1 \mathrm{~N} *$ & 1t* & $\mathrm{TR} * *$ \\
\hline Carpet Weaving & May, 95 ". & Kariz Khoni & Kushk & 6 Months & 1 & 1 & 10 \\
\hline Carp $x$ Weaving & May, 95 & Dezwari & Kushk & 6 Months & 1 & 1. & 15 \\
\hline carpet Weaving & May, 95 & Kalakhoran & Kushk & 6 Months & 1 & 1 , & 8 \\
\hline Carpet Weaving & May, 95 & Faizabad & Kushk & 6 Months & 1 & 1 & 10 \\
\hline Carpet Weaving & May, 95 & Khalawak & Kushk & 6 Months & 1 & 1 & 7 \\
\hline Carpet Weaving & May, 95 & Rabat Sangi Ulia & Kushk & 6 Months & 1 & & 10 \\
\hline Carpet Weaving & May, 95 & Rabat Sangi Sofla & Kushk & 6 Months & 1 & 1 & 10 \\
\hline \multicolumn{5}{|c|}{ TOTAL PARTICIPANTS } & 7 & 7 & 70 \\
\hline
\end{tabular}

* : Instructor (IN.)

** : Literacy Trainer (LT.)

$\star \star \star$ : Trainees (TR.)

$\star \star \star \star$ : Chowkidar $(\mathrm{CH}$.)

\section{Remaining Activities from 1994:}

Out of seven vocational mobile training centers, started in 1994, three were completed during that year, but the following four of them, due to late approval of the budget, remained for 1995:

\begin{tabular}{|c|c|c|c|c|c|c|}
\hline \multirow[t]{2}{*}{ No } & \multirow{2}{*}{ Type of Course } & \multicolumn{2}{|l|}{ Location } & \multirow{2}{*}{$\begin{array}{l}\text { Date } \\
\text { Started }\end{array}$} & \multirow[t]{2}{*}{ Ending date } & \multirow[t]{2}{*}{ \# of Trainees } \\
\hline & & Village & District & & & \\
\hline 1 & Carpet weaving & Boshran & Enjil & 17.4 .94 & 11.4 .95 & 15 \\
\hline 2 & Carpet weaving & Spfian : & Enjil & 29.3.94 & 29.3.95 $\div$ & 8 \\
\hline 3 & Carpet Weaving & Paychanar & Gozara & 20.6.94 & 1.8 .95 & 7 \\
\hline 4 & Carpet Weaving & Kurt & Gozara : & 23.6.94 & 1.8 .94 & 5 \\
\hline \multicolumn{6}{|c|}{ Total } & 12 \\
\hline
\end{tabular}

The first two courses have been completed and the graduates received tools and equipment along with their certificates.

The following table provides information about repayment rate of the graduates of the last: year's skills training courses who received tools and equipment of their learned skills on a $50 \%$ subsidized loan basis:

\begin{tabular}{|c|c|c|c|c|c|}
\hline No & Skills & No of, articipant & Amount & Amount & Balance \\
\hline 1 & Embroidery & 25 & 36,974 & 7,500 & 29,474 \\
\hline 2 & Carpet Weaving & 33 & 32,691 & 3,600 & 29,091 \\
\hline
\end{tabular}




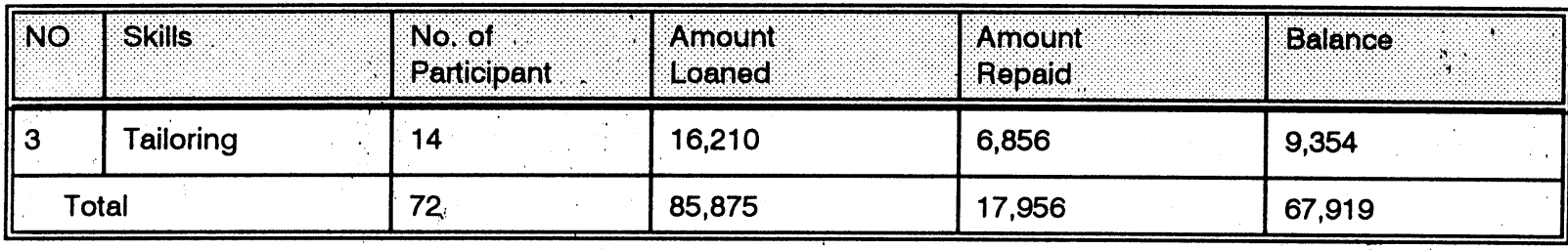

Total amount paid makes $21 \%$ of the total loaned amount. The repayment of the tailors ranks the highest while that of the carpet weavers ranks the lowest.

The table below provides information regarding the repayment rate of those skilled women who received tools and equipment on loan basis. Total amount repaid makes $6 \%$ of the loaned figure, with the tailoring ranking lowest and the silk worm ranking highest:

\begin{tabular}{|c|c|c|c|c|c|}
\hline No & Skills & No of & Amount & Amount & Balance \\
\hline 1 & Silk Worm Raising & 3 & 19,305 & 2,160 & 17,145 \\
\hline 2 & Carpet Weaving & 12 & 74,880 & 7,540 & 67,340 \\
\hline 3 & Tailoring & 9 & 106,095 & 2,295 & 103,800 \\
\hline$T$ & $\begin{array}{llll}0 & t & a & 1\end{array}$ & 24 & 200,280 & 11,995 & 188,285 \\
\hline
\end{tabular}

In addition to the activities mentioned; the program monitored the ongoing courses and the participants of the previous courses. The program expenses in the past six months constituted $9.5 \%$ of the actual budget.

\section{VOCATIONAL TRAINING PROGRAM FOR DISABLED}

\section{Survey and Identification:}

According to a survey that took place at the end of 1994 and early 1995 in the villages of Chaqumaque and Karukh "center of "Karukh district; and in the villages of Marghaz, and, Akhundan of Enjil district; the program was not able to establish any courses because, on the one hand, the budget was not received in due time, and on the other hand, the trainees wanted food-stuff which was contrary to the training policy of NPO/RRAA. Only one tailoring course was established in Enjil district. This course became active in Babaji village with 6 disabled on 25.5.95. The course is going on with one trainer, who, in addition to carrying out the skill training, carries qut the literacy program of the trainees, too. This course has been monitored twice a week.

\section{Second Sub-Identification:}

In the subsequent survey in the districts of Kushk and Gulran in the month of May, 44 disabled were selected from different villages for different professions according to their own interests, abilities, and the community market needs.

Kushk and Gulran districts were selected because, on the one hand, the people are very poor and on the other hand, these districts are secure and safe. 
The following table shows the selected mobile vocational training courses which have already been identified:

\begin{tabular}{|c|c|c|c|c|c|c|c|}
\hline \multirow{2}{*}{ COURSE TITLE } & \multicolumn{2}{|l|}{ LO০AION } & \multirow[t]{2}{*}{ COURSE } & \multicolumn{4}{|c|}{ PARTICIPANTS } \\
\hline & $\mathrm{VIL} \triangle A G E$ & $\mathrm{DIST}$ & & $\mathrm{N} *$ & LT** & $\mathrm{TR} * * *$ & $\mathrm{CH} / * \star *$ \\
\hline Carpentry & Rabat Sangi Ulia & Kushk & 6 Months & 1 & 1 & 7 & 1 \\
\hline Tailoring & $\begin{array}{l}\text { Rabat Sangi } \\
\text { Sofla }\end{array}$ & Kushk & 4 Months & 1 & 0 & 3 & 0 \\
\hline Carpet Weaving & Parwana & Kushk & 6 Months & 1 & 1 & 4 & 1 \\
\hline Carpet Weaving & Faizabad, Hafto & Kushk & 6 Months & 1 & 1 & 5 & 1 \\
\hline Tailoring & Dezwari & Kushk & 4 Months & 1 & 1 & 6 & 1 \\
\hline Carpet Weaving & Khalawak & Kushk & 6 Months & 1 & 1 & 4 & 1 \\
\hline Tailoring & Yaka Darakht & Kushk & 4 Months & 1 & 1 & 6 & 1 \\
\hline Radio Repairing & Qara Bagh & Gulran & 6 Months & 1 & 1 & 4 & 1 \\
\hline Carpet Weaving & Mesh Mast & Gulran & 6 Months & 1 & 1 & 5 & 1 \\
\hline \multicolumn{4}{|c|}{ TOTAL PÁRTICIPANTS' } & 9 & 8 & 44 & 8 \\
\hline
\end{tabular}

* : Instructor (IN.)

** : Literacy Trainer (LT.)

$\star \star \star \quad$ : Trainees (TR.)

$\star \star \star \star$ : Chowkidar $(\mathrm{CH}$.

The above mentioned courses will start when the second sub-proposal would be approved.

The vocational training courses will be run in the selected villages in the house compound of the participants or, in the house compounds selected and contributed (for the period af training) by the elders of the community. Each course will run for six hours a day and six days a week according to a curriculum and a work plan. One trainer in each course, locally hired for the period of training, will be involved in offering training. A literacy trainer will run one hour literacy sessions.

\section{Remaining Activities From 1994:}

The graduated trainees who were trained during 1994 , received tools and equipment on a $50 \%$ subsidized loan basis that should be repaid within 18 months. Of the total amount loaned $11 \%$ has been collected during the last six months. The following table provides information about the repayment of the loans:

\begin{tabular}{|c|c|c|c|c|c|}
\hline No & SKILLS & No. OF & $\begin{array}{l}\text { AMOUNT } \\
\text { LOANED }\end{array}$ & AMOUNT REPAID & BALANCE \\
\hline 1 & Carpentry & 19 & 12,416 & 930 & 11,486 \\
\hline 2 & Tailoring & 27 & 27,493 & 6,552 & 20,941 \\
\hline \multicolumn{2}{|c|}{ Total } & 46 & 39,909 & 7,482 & 32,42 \\
\hline
\end{tabular}


In the end of 1994 and the beginning of 1995, loans were provided to 31 skilled disabled and poor men in Baghi Zaghan, Dagh Abad, Baghi-Dasht, Marghaz, Rabat Darwish and Mir: Haider villages of Enjil district and in Pashtan, Islamabad, and Chaqumaque villages of Karukh district. The participants were monitored and the installments were collected in the past six months. The total amount collected makes $14 \%$ of the total amount loaned. The following table exhibits details of the activity:

\begin{tabular}{|c|c|c|c|c|c|}
\hline No & SKILLS & NO OP & AMOUNT & AMEPANT & BALANCE \\
\hline 1 & Embroidery $\therefore$ & 1 & 7,000 & 1,100 & 5,900 \\
\hline 2 & Carpet Weaving & 13 & 26,623 & 1,567 & 25,056 \\
\hline 3 & Butcher & 1 & 6,500 & 1,100 & 5,400 \\
\hline 4 & Shopkeeper & 16 & 70,536 & 11,336 & 59,200 \\
\hline \multicolumn{2}{|c|}{ Total } & 31 & 110,659 & 15,103 & 95,556 \\
\hline
\end{tabular}

The program expenses in the past six months constituted $8.7 \%$ of the actual budget.

\section{CONSTRUCTION PROGRAM}

Under this program, five primary schools are to be reconstructed in various villages of Kushk district which is located $50 \mathrm{~km}$ to the north of Herat city. This districts is one of the least developed areas of Herat province. These schools were active before the war and more than 1,000 students were attending these schools.

\section{a. Darwish Ali Primary School:}

This school belongs to Kushk district of Herat province, $20 \mathrm{~km}$ on the east of the district. (250) students attend this school which come from (8) villages, comprising of:

1. Karez Khoni 2. Qala-i-Safed" 3. Qala-i-Darwish 4. Kach Call 5. Qaria Tano Shabaik 6. Qala-i- Fazel Ahmad 7. Afghanha 8. Qala-i-Kunjak

Ttotal papulation of the above mentioned villages is around $(6,000)$ persons. This school was active before war but during the war, was destroyed and became inactive Faimuri and Jamshidi Tribes live in these villages. Construction of this school started in April 95, and until the end of June aboüt-98\% of its work have been completed. Contribution of people, amounted to Rs.32,068.

\section{b. Doaab Primary School:}

Located $6 \mathrm{~km}$ to the north-east of Kushk district, this school provides education for 204 students who come from the following four villages: 1 . Khodraw village, 2. Lower Doaab village, 3. Upper Doaab village and 4. Lakhi village. This school was destroyed about $50 \%$ during the war. Jamshidi tribe makes the majority of population. Total population of all 4 villages are 2,200 persons. Rehabilitation of the school started in April and until the end of June, 95 about $85 \%$ of its work has been completed. Contribution of the people and the government amounted to Rs. 47,490 out of which the government share was 8 metal pipes, each $6 \mathrm{~m}$ long, for the covering of the roofs of the rooms. 


\section{c. Yaka Darakht Primary School:}

Located $20 \mathrm{~km}$ to the north-eașt of the district center, this school provides education for 145 students who come from the following three villages: 1. Kalla Khore 2. Khalafa 3. Yaka Darakht. Total population of these three villages are (1800) persons. Jamshedi and Zohory Tribes live in these villages. The work on this school started in April 95 and by the end of June, about $69 \%$ has been completed. Contribution of people amounted to Rs.30,605:

\section{d. Khalifa Rahmat Primary School:}

Located $40 \mathrm{~km}$ to the north-west of the district center, this school provides education for 164 students who come from the following three villages: 1. Khalifa Rahmat Village 2. Seezwar 3. Tolgai 4. Qoachi village. Total Population of these 4 villages are 2,170 persons. The majority is Taimuri, but Turkaman and Zohori are living in these villages, as well. The work on this school started "on 23.05 .95 and about $30 \%$ of its work has been completed up to the end of June, 95. Contribution of the local community amounted to Rs.16,500. Contribution of the government is comprising of 36 metal pipes for the covering of the roofs. Estimated value of the pipes was Rs.72,000: 5,000 msq. land for construction of the school was contributed by the local people which valued to an estimated amount of Rs.50,000. Total community and the local government contribution for the school was Rs. 138,500.

The following table provides detail of the activities:

\begin{tabular}{|c|c|c|c|c|c|c|}
\hline No & School Name & No. of & No. Ot & $\begin{array}{l}\text { Date work } \\
\text { Started }\end{array}$ & $\begin{array}{l}\text { Work } \\
\text { Progress } \\
\text { \%gge }\end{array}$ & $\begin{array}{l}\text { End Of } \\
\text { Work }\end{array}$ \\
\hline 1 & Doaab Primary'school & 9 & 204 & 1.4 .95 & $85 \%$ & 30.8 .95 \\
\hline 2 & $\begin{array}{l}\text { Darwish Ali Primary. } \\
\text { School }\end{array}$ & 8 & 250 & 1.4 .95 & $98 \%$ & 30.7 .95 \\
\hline 3 & $\begin{array}{l}\text { Yaka Darakht Primary } \\
\text { School }\end{array}$ & 7 & 145 & 12.4 .95 & $69 \%$ & 30.9 .95 \\
\hline 4 & $\begin{array}{l}\text { Khalifa Rahmat } \\
\text { Primary S'chool }\end{array}$ & 7 & 164 & 23.5.95 & $35 \%$ & 30.11 .95 \\
\hline 5 & $\begin{array}{l}\text { Dezwary Primary } \\
\text { School }\end{array}$ & 7. & 130 & 5.7 .95 & $0 \%$ & 30.12 .95 \\
\hline
\end{tabular}

The table below provides information regarding community and government contribution towards the projects:

\begin{tabular}{|c|c|c|c|c|c|c|}
\hline \multirow[t]{3}{*}{ School Name } & \multicolumn{3}{|c|}{ Community contribution } & \multicolumn{2}{|c|}{ Government contribution } & \multirow{3}{*}{ Total } \\
\hline & \multicolumn{2}{|l|}{ Typo } & \multirow{2}{*}{ Value } & \multirow{2}{*}{ pipes contributed } & \multirow[t]{2}{*}{ Value } & \\
\hline & Labor (man day) & land & & & & \\
\hline Doaab & 488 & 0 & 29,890 & 8 & 16,000 & 45,890 \\
\hline Derwish Ali & 377 & 0 & 30,065 & 1 & 2,000 & 32,065 \\
\hline Yaka Darakht & 472 & 0 & 30,605 & 0 & 0 & 30,605 \\
\hline Khalifa Rahmat & 355 & $5,000 \mathrm{~m}^{2}$ & 66,500 & 36 & 72,000 & 138,500 \\
\hline
\end{tabular}




\begin{tabular}{|c|c|c|c|c|c|c|}
\hline \multirow[t]{3}{*}{ School Namo } & \multicolumn{3}{|c|}{ community contribution } & \multicolumn{2}{|c|}{ Government Gontribution } & \multirow{3}{*}{ Valuo } \\
\hline & \multicolumn{2}{|c|}{ Yypo } & \multirow{2}{*}{ Yalue } & \multirow{2}{*}{ popes } & \multirow[t]{2}{*}{ Value } & \\
\hline & 6 abon $($ man oay) & 1010 & & & & \\
\hline Dezwary** & 0 & 0 : & 0 & 0 & 0 & 10 \\
\hline$T \circ \quad t a \quad 1$ & 1,692 & $5,000 \mathrm{~m}^{2}$ & 157,060 & 45 & 90,000 & 247,060 \\
\hline
\end{tabular}

* Participants; refers to the number of man-day

** : The construction work of Dezwary primary school will start next month.

Actual community contribution made up $80 \%$ of the original plan. The program expenses in the past six months constituted $8.6 \%$ of the actual budget.

\section{SHELTER PROGRAM:}

Thousands of external refugees and Internally Displace People (IDP) have returned from Iran and other provinces of Afghanistan. Therefore the shelter program was designed to assist these returnees with building bașic shelters which, on a later stage, might develop into a more permanent houses.

This program was funded by NCANRC, UNHCR sub-office Herat and WFP sub-office Herat. The target was fixed for 1,000 unit shelters. For the implementation of the program, 6 staff members, under the supervision of Herat regional office, have been involved.

The identification of the participants started in Zandajan district on 19 Oct., 1994 and completed on 15 Dec., 1994. As a result of a survey, 1,000 returnees were selected from 62 villages of the said district. The delivery of food-stuff and toolkits for construction of 1,000 participants' shelters' were completed by the end of March 1995. In connection to that, each participant received a set of construction toolkits along with $200 \mathrm{~kg}$ wheat.

\section{EMERGENCY RELIEF PROGRAM:}

Lack of security drove more than 1,000 families from different provinces of Afghanistan, particularly, from Kabul to Herat city, and the number has been increasing. 750 internally displaced families from Kabul and other provinces have been identified in cooperation with UNHCR, Herat and Repatriation Department, Herat Province. The identified families, located in Alfateh Camp, Old Transit Center, and localities around the city of Herat, were assisted with the following items, during the past six month:
No.
Items
Amount
1. Rice
$50 \mathrm{~kg}$ per family
2.
Cooking oil
$12 \mathrm{~kg}$ per family
3.
Quilt
2 unit per family 


\section{JALALABAD REGIONAL OFFICE}

In 1995, Jalalabad Regional Office, implemented projects in Laghman and Nangarhar provinces with an annual budget of Rs.9,356,000 which made about $18.2 \%$ of the total NPO/RRAA's annual budget, and a total staff of 48 people that comprised $19.9 \%$ of the NPO/RRAA's total staff.

During the first four months of this year the security situation of Nangarhar province was 'peaceful. However, in the last two months, on one hand, the security situation slightly dereriorated and, on the other hand, the regional Shura assumed stricter policies regarding the work of women in the aid agencies in Jalalabad and Laghman.

\section{ACHIEVEMENTS:}

All the projects of the region were implemented in the following four sectors:

1. CONSTRUCTION

2. EDUCATION

3. INCOME GENERATION

4. POULTRY

\section{CONSTRUCTION PROGRAM}

This program implemented the following projects:
A. Qarghai Bridge (ongoing)
B. Senzai bridge (ongoing)
C. Behsood High School (ongoing)
D. Mashakhail Primary School
E. Kamal Poor Middle School
F. Aimal Khan High School
G. Islamabad High School
H. Road Rehabilitation, Ali Shing

\section{A. QARGHAI BRIDGE (ongoing):}

Located $15 \mathrm{~km}$ to the east of Mehterlam, the center of Laghman province, this steel bridge was built by Britisth colonialists around 100 years ago. The bridge is $75 \mathrm{~m}$ long and $5 \mathrm{~m}$ wide.

Rehabilitation of the bridge started in the year 1994. During last year, the trusses of the both sides of the bridge were repaired; channels over the "I" beams were fixed; and, flat slabs over the channels were fixed:" The initial plan was $85 \%$ completed during 1994 . The reason for this shortfall was the unavailability of some steel plates in the local market. 110 plates were ordered from Pakistan.

Meanwhile, the local Shura and the inhabitants of Qarghaie district submitted a request to JRO which demandēd the rebuilding of the wing walls of the bridge, which was not part of the original work plan. To meet their demand, JRO submitted a proposal to the regional office' of WFP in Jalalabad for $18.5 \mathrm{mt}$ of wheat. Although the proposal was not approved, JRO 
managed to complete the side wings and painting of the bridge. The work was completed in April 1995.

Before the work started, an agreement was signed with the Qarghaie Shura to ensure their contribution and participation in the reconstruction and maintenance of the bridge. According to the agreement the community was to contribute $10 \%$ of the raw materials, like gravel and stone. In addition, '600 manual workers were, as well, to work without charges in the reconstruction of the bridge. Estimated community contribution to the project was around 200 man-days work, an equivalent of Rs.12,500. All inhabitants of the district, around 176,000 people, will benefit from this project.

Rehabilitation of this bridge makes the route between Laghman and Jalalabad $10 \mathrm{~km}$ shorter. The bridge is also used as a short link between the Laghman capital and Char bagh area of Laghman Province. 220,000 inhabitants of the Qarghai district and the people from Mehterlam, Alishing, Alingar and Dawlat Shah districts will benefit from the bridge. Construction of the bridge provided jobs for a group of 15 welders (for six months), 6 painters (for two months), and three staff of NPO/RRAA.

\section{B) SENZAI BRIDGE:}

Located in the Senzaie village of Peech Valley, $40 \mathrm{~km}$ west of Asadabad city, the capital of Kunar province, this steel bridge is 30 meters long and 4.5 meters wide. Construction of the bridge started in March 1993. Building of the abutment, wing walls, gabions, and welding of the trusses were completed. However, the work on the bridge was stopped on 5 May because the Pakistani welders, a contractor of the project, did not continue their work. The major remaining task was to pull the truces over the bridge that undoubtedly was a challenge. On 25 July 1994 an agreement was signed with another welder; according to which he was to finish the pulling work of the trusses within two months, upto 10 October 1994. He started on 10 August 1994, but unfortunately was not able to finish the work in the time specified. To help him complete the job, JRO assigned two qualified construction engineers to help the welders. Unfortunately, the work wa's not completed in 1994.

The following activities were performed on Senzai bridge during the first six months of 1995:

a. The broken part of the one trusses has been repaired.

b. Both trusses have been welded by $5 \mathrm{~mm}$ welding rod.

c. The nuts and bolts of both trusses were done.

d. Both trusses were pulled and fixed on the abutments.

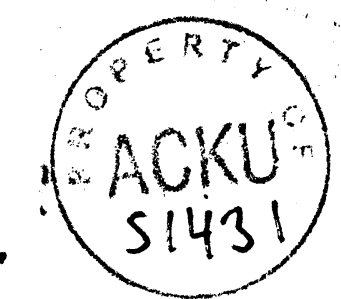

The above mentioned work was completed up to April 1995. Due to a budget shortage, the practical work on the bridge was stopped from April up to end of June. The extra budget, Rs. 360,000 , was approved for the remaining work of the bridge in the end of June, so the practical work of the bridge will be started again in July 1995. According to the new plan the remaining work will be completed by 14 October $1995.90 \%$ construction work of this bridge has so far been completed.

The bridge will benefit more than 20,000 families. During the summer and spring seasons the water level rises and the travellers, in the absence of a bridge, face difficulties, assume great 
risks, and pay lots of money to cross the river. Construction of this bridge will solve these problems. In the meantime, the transportation fare will be reduced by $25 \%$.

The community contribution level was very high. 600 manual workers participated in the leveling of one side of the abutment without any charges. Estimated community contribution from the beginning of the project till June 1994 was Rs. 30,000. In 1995, the local Shuras of Senzai, Kandi, Kala, Gulsalak and Chapadara villages have promised to contribute $100 \%$ of the labor work in the leveling of two sides of abutments and construction of two side walls.

During the first six months of this year, the project provided jobs for a group of 10 welders, and 15 villagers from Senzai village. The population of Senzai village, Kandai village, Kala village, Gul Salak village and Chapa Dara that belong to Safi, Gurbuz, Wader and Masood tribes of the Pushtoon and Pashai'ethnic groups will benefit from this project.

\section{C) BEHSOOD HIGH SCHOOL:}

Construction of Behsood Middle School, a 6-classroom building, started on 14 June 1994 and by the end of October 1994 the original plan was completed. However, in the middle of the year the school was promoted to a high school and the community requested for more classrooms to be built. After assessing the project's financial condition it was decided to build five more rooms in addition to the previous six classrooms + one office room. Initially, the duration of the project was six months, which was ended in November 94, but the extended work was completed in April 1995.'

According to an agreement signed with the elders of the community and the governor of Behsood District, a committee of 10 people from the local residents was formed to supervise the construction of the school. The committee, as well, was responsible to arrange free labor for the project. Estimated community contribution in labor work form was an equivalent of Rs.6,125. WFP Jalalabad, under its Food for Work program, provided $84 \mathrm{mt}$ wheat for the labor wage of the project.

500 students ( 100 girls and 400 boys) are expected to get education at this school. 12,000 inhabitants of 10 villages who belong to Pushtoon and Tajik ethnic groups, will utilize the school.

Another proposal was submitted to WFP office for the labor wages and the raw material of the three class rooms, six latrines and fence around the school, therefore the amount of 48 M.T wheat was approved by WFP office. The following work was done during the first six months of 1995 :

a. The construction work of 3 new class rooms has been completed.

b. The construction work of the fence around the school has been completed.

The Education Department of Jalalabad has taken the responsiblity of the running of the school, while the district admin. office will look after its maintenance.

\section{MASHAKHIL PRIMARY SCHOOL:}

Located in the Mashikhil village of Qarghaie district, Laghman, Mashakhil primary school with its 6 class rooms has been destroyed during the war. Before the war, 800 students from grade one to six used to attend the school. Currently, some 400 students (200 girls and 200 boys) from grade one to six are attending school in an open area. This school is being run 
jointly by the Swedish Committee for Afghanistan (SCA) and Education department of Laghman province.

Rehabilitation of this school was funded by the World Food Program (WFP), Jalalabad Sub Office. For the first phase of the reconstruction of the school (building of 4 class rooms), the Regional Office of Jalalabad received 46.3 M.T wheat from the WFP office in Jalalabad. The. following activities were performed in Mashakhil school:

a. Constructing 4 class rooms

b. Digging a well in the school area.

400 students per year, both girls and boys, and the inhabitants of 7 villages with an approximate population of 10,000 persons will benefit from rehabilitation of the school building. The land for reconstruction of this school was contributed by the community.

\section{E. KAMAL PUR MIDDLE SCHOOL:}

Kamal Pur school is located in Kamal Pur village $4 \mathrm{~km}$ from the Qarghai district administration office and $19 \mathrm{~km}$ south-east of Mehterlam city (center of Laghman province). Currently, some: 450 students from grade one to eight are attending the school in an open area. This school is being run by Swedish Committee.

The rehabilitation of this middle school will enable the inhabitants of around 12 villages, Daralam, Bolan, Kamal Pur, ¿Doranghar, Lumati, Mashina, Husssain Abad, Shirtabad, Buluchabad, Miakhil, Nawar and Kalagai with an approximate population of 12,000 people, to get access to education. Some $\mathbf{4 5 0}$ students per year will receive education in this school.

This school was funded by the World Food Program (WFP) Jalalabad Sub Office. For reconstruction of the first step ( 5 class rooms) of this school the Regional Office received 47.6 M.T wheat from-WFP office. Construction work of the 5 class rooms have been completed. The land for construction of this school contributed by the community.

\section{F. AIMAL KHAN HIGH SCHOOL:}

Located to the east of Jalalabad city in Momand Dara district on Jalalabad Torkham high way, this high school was destroyed during the war. During 1993 \& 1994 its reconstruction, funded by NCA/NRC, was untdertaken by ERSA. The organization was unable to complete the work; hence the remaining work was contracted by NPO/RRAA's JRO. Total expenses in the past six months made up $69.4 \%$ of the actual budget of the project. The following work has been performed by NPO/RRAA's Jalalabad Regional Office:

a. Construction of a water tank with the capacity of $8 \mathrm{~m}^{3}$

b. Construction of 6 latrines

c. Concrete around the main building

d. Provision of "120 benches, 130 chairs, and some stationary

\section{G. ISLAMABAD MIDDLE SCHOOL:}

Islamabad Middle School with 9 class-rooms, which was destroyed during the war, is located in Islamabad village of Alishing district, Laghman. level of war destruction in the district is 
high. The inhabitants of the district, who are all followers of the sunni sect of Istam belong to Pashai, Pashtoon and Iajik ethnic groups.

The rehabilitation of the middle school will enable the inhabitants of around 15 villages with an approximate population of 15,000 to get access to education. Some 500 students per year +25 teachers and staff of the school will directly benefit from the school. 7 skilled labours; 21 unskilled labours + 3 NPO/RRAA staff will directly benefit from this project. $10 \%$ construction work of the school was.completed. Total expenses in the past six months made up $6.9 \%$ of the actual budget of the project.

An agreement was signed with the governmental and local community authorities regarding their contribution in reconstruction of the school. The community made a commitment to contribute to the project in various forms:

a. Labor Wages: The Labor wage in the area is Afs.5,000 per day, while the laborers working on the school will receive Afs.3,500 per day; Afs. 1,500 will be contribution of each laborer per day.

b. Raw Materials: The cost of each cubic meter stone and sand is Afs.15,000 in the area but the community will provide each cubic meter stone and sand for Afs. 11,000 .

c. Cash Contribution: The inhabitants of 15 villages, around 2,000 families will pay Afs. 1,000 per family as a cash contribution for the reconstruction of this school.

d. Land for Construction: The local Community provided land for reconstruction of this school.

\section{H. ROAD REHABILITATION PROJECT}

A 2,000 $\mathrm{m}$ road, located between Islamabad village and Gargar village, Ali Shing district, Laghman, has been severly damaged, and needs repairing plus a total of $220 \mathrm{~m}$ retaining walls. The road is being used by the inhabitants of Mehterlam, Mia Saheb, Kotaly; Jam Shirabad, Ghaziabad, Nora, Qala villages, a population of about 150,000 people, and ravellers from Dawlat Shah district. $10 \%$ construction work of the road has been completed. An agreement was signed with the governmental and local authorities regarding their contribution in rehabilitation of this road.

Construction of this road provides jobs for seven skilled, and 21 unskilled local workers, and one civil engineer. The inhabitants of above mentioned villages and the population of Dawlat shah district will benefit form this ro'ad. The communiy contributed to the project in various forms:

Labor wage in the area is Afs.5,000 per day, while the laborers working on the street got: Afs.3,500 per day so, Afs. 1,500 was contribution of each laborer per day. The villagers will be contributing $25 \%$ of the total costs of local raw materials such as stone and sand. Total expenses in the past six months made up $28.6 \%$ of the actual budget of the project.

NPO/RRAA, Semiannual Report 1995 


\section{EDUCATION PROGRAM}

During the first six months of 1995, Education program has been running well in Hesar Shahi camp, Iraq Rehabilitation Organization (IRO) camp, New Hadda camp, Nangarhar province and Islam Abad village, Ali Shing district, Laghmah province.

Hesari Shahi camp is located to the east of Nangarhar province about $23 \mathrm{Km}$ from Jalalabad city. At the present moment, there are 39 blocks, each containing 8 sections. There are 40 or more families in each section.

STOP model seminars for Female in blocks\# $32,35,36,37,38$ and 39 were held in January and February, 1995. Totally 262 women participated in these seminars. The total number of children, assisted with playing and learning materials were 1,105 ( 358 male, 747 female).

Stop model seminars have been held in 64 blocks at IRO camp. IRO camp contains 64 blocks, each consists of 20 tents, i.e., twice the size of blocks' in Hesar Shahi camp. A Total of 136 persons ( 74 male, 62 female) participated in these seminars. As a result of these seminars, 1486 ( 866 male, 620 female ) Kabuli displaced children were assisted with the playing and learning materials.

In Islamabad village of Ali shing district of Laghman province, Stop model seminars have been held in Mach 1995. Totally, 223 persons( 161 male and 62 female) participated these in the seminars. As a result of these seminars, 722 children ( 619 male, 103 female ) were assisted learning and playing materials.

New Hadda camp, located to the south-west of Jalalabad city, consists of 24 blocks. Stop model seminars have been held in blocks \#1,2,3,4,5,6,7,9, and 10, in New Hadda camp, in March 1995. Totally, 650 persons ( 419 male and 231 female) participated in these seminars. As a result, 5504 Kabuli displaced children ( 4008 male , 1496 female) were assisted learning and playing materials to start self help activities.

The following table shows activities of the education program:

\begin{tabular}{|c|c|c|c|c|c|}
\hline \multirow[t]{2}{*}{ No: } & \multirow[t]{2}{*}{ Style of Activities } & \multirow{2}{*}{$\begin{array}{l}\text { No of } \\
\text { Classes }\end{array}$} & \multicolumn{2}{|c|}{ No of Chilldren } & \multirow[t]{2}{*}{ Tota } \\
\hline & & & Boys & Girls & \\
\hline 1 & Kindergarten & 70 & 857 & 1069. & 1926 \\
\hline 2 & Religious courses & 58 & $1206^{\cdots}$ & 642 & 1848 \\
\hline 3 & literacy courses & 114 & 406 & 1052 & 2547 \\
\hline 4 & English courses & 15 & 361 & $\cdot 11$ & 301 \\
\hline 5 & Math \& science & 18 & 415 & 63 & 478 \\
\hline 6 & Calligraphy courses & 9 & 91 & 88 & 179 \\
\hline 7 & Delineation Courses & 2 & 0 & 39 & 39 \\
\hline 8 & Volley Ball Teams & 88 & 1187 & 0 & 1187 \\
\hline 9 & Foot Ball Teams & 10 & 239 & 0 & 239 \\
\hline \multicolumn{2}{|c|}{ Total } & 382 & 5851 & 2964 & 8815 \\
\hline
\end{tabular}




\section{Staff Training:}

A training seminar has been held in cooperation with the Swedish Committee for Afghanistan (SCA) at the NPO/RRAA's Jalalabad office from April 14-18, 1995. Six members of education staff participated in this seminar. The topics, covered in the seminar, were Management, Evaluation and Monitoring.

Another series of training seminars with the cooperation of Radda Barnen, started in February 1995 at the NPO/RRAA's Jalalabad office, will continue up to the end of 1995. Six members of education staff are attending these seminars. These seminars cover the following topics: Handicap, Mental Handicap, Behavior to Handicap and children with special needs.

The team leader of the education program participated in the training work shop held by Radda Barnen in Peshawar from Junne $24-28,1995$. The workshop dealt with issues such as needs and rights of children.

Two female staff members have been introduced to a Kindergarten training program held by IRC in Peshawar from 9 March to 9 July 1995.

\section{Distribution:}

The following materials have been distributed to the children participated in the self-assisted classes:

1. Ball point pens, pencils, notebooks, sharpeners, erasers for all the children participated in the classes

2. A net and a ball for each volleyball team

3. A nursery kit for each kindergarten.

\section{Monitoring:}

Regular monitoring of the activities were carried out in Hesari shahi camp, IRO camp, New, Hadda camp and in Islamabad village. Some of the volunteer teachers have gone to Kabul for a short period of time. During this period the children didn't have classes. At the IRO camp, the program participants were told by the responsible agency that it wouldn't provide ration for them any more, as the situation in Kabul was calm and they can go to their own home city. Some of the tents were collected by their owners and they have gone to their own home towns. Our activities, subsequently, were reduced in IRO camp. Also some of the activities were stopped in Hesari Shahi camp as some of the volunteer teachers went to Kabul. Total expenses in the past six months made up $24.4 \%$ of the actual budget of the program.

\section{INCOME GENERATION}

This sector encompassed the following five components:
A. Income Generation Program for Female
B. Income Generation Program for Disabled Male
C. Loan Scheme Project

NPO/RRAA, Semiannual Report 1995 


\section{Cemmunity Supprot Program \\ E. Fism Mechanized Station Program}

\section{A. WCOME GENERATION PROGRAM FOR FEMALE}

7tre program consisted of three types of activities:

\section{a. Live stock and Poultry:}

A survey was carried out in Ali Shing district, Laghman province for the needy widows and the most vulnerablr and poor women. 24 women were selected to be assisted. Out of 24, 19 received two sheep or two goats, each. The other 5 were provided chicks to establish small: poultry farms. The participants reside in Islamabad, Sharbat khail, Alai ghundi, Kadrdu and Barikzai villages.

b. Tree Nursery: Will be implemented in the next six months.

c. Skills Training Will be implemented in the next six months.

\section{d. Ongoing activities from 1994 :}

1) 13 women were graduted form a tailoring course in Alishing district on 20 May 1995. The course was opened on 25 December 1994. They were provided with sewing: machines and other tailoring tools at subsidized prices to be repaid in instalments.

2) 10 women, who graduate from a tailoring course in Bakhtan village, Surkh road district, in September 1994, were monitored. They repaid all their dues. Their average daily income, according to the monitoring reports, was Rs. 25 to Rs. 30 .

3) Sixteen women, assisted with 2 milking goats each in Beland Ghar of Behsood district and in Kanda village of Qarghaie district in 1994, paid all their dues and showed an average daily income of Rs. 25 per person.

4) 78 widows have been assisted through tree nursery programs in 1994 in Nangarhar and Laghman provinces. The saplings, produced in their nurseries, were ready for; distribution that the Nangarhar. Shura banned all female programs; therefore, the distribution was postponed until restarting the female program activities.

Total expenses in the past six months made up $41 \%$ of the actual budget of the program.

\section{B. INCOME GENERATION PROGRAM FOR DISABLED}

The program target for the current year was to assist some 30 vulnerable disabled men by offering training and/or tools and equipment of a skill.

A survey was carried out in Ali Sheng district, Laghmsn province. Consequently, 11 needy disabled men were selected for assistance. Out of 11,6 were selected to establish small, poultry farms, 2 to raise live stock, 1 skilled man for carpentry, and 2 for tailoring training.

22 disabled who graduated from tailoring courses in Laghman in last November, were monitored. They paid their first instalment of their dues from tools and equiqment loaned.

NPO/RRAA, Somiannual Roport 1995 
10 gratuated trainees of Momand Dara district tailoring course, Nangarhar province, which. was ended on 2 Növember 1994, paid their dues regularly.

Nine graduates of a tailoring course in Kanda village of Qarghai district, Laghman province, ended in september 1994, paid thieir two instalments in full. Total expenses in the past six months made up $37.5 \%$ of the actual budget of the program.

\section{LOAN SCHEME PROJECT}

As an experiment, the project was started in 1994 and nine people, including small farmers, carpet weavers, and welders, both disabled and able-bodied, were given small loans to establish their own busnisses. No new loans were given in 1995; however, $40 \%$ of Rs.126,000, the total loaned amount in 1994, were collected during the last six months.

\section{COMMUNITY SUPPORT}

The program carried out a survey in Alishing district, Laghman to assess the rural communities' needs and, in cooperation with them, solve those problems. The following activities were implemented as a result of this survey:

a. One well digger was provided tools and equipment to dig a shallow well in the center of Dagian village. Sixty families and the students of Dagian school use the well water.

b. A 40m-long Kariz in Gachian village was cleaned. Tools were provided by the program, while the community shared the labor force for the activity. Sixtly families will use the water for drinking and irrigating of their 300 Jeribs of land.

c. Anothe $50 \mathrm{~m}$ Kariz in Khawal village was cleaned under the same provisions as the above Kariz. Thirty families will use the water for drinking and irrigating their 200 Jeribs of land.

\section{Flour Mills:}

There are three mills operating in various communities under this program:

1. Hadda Mill: This mill was established in 1993 and was runnig until the end of 1994. JRO decided to hand over the mill to the local community. Since begging of the year, several meetings have been held with the community people and local authorities to negotiate the matter. Due to some difficulties, the office was not able to carry the task out. The mill will be handed over to the local community in the second half of the year.

2. Gambiri and Shamakat Mills: Located in Gambiri village, Qarghaii district, and Shamakat village, Alishing district, Laghman, these two mills were established in 1994. They both are functioning actively'. The following list shows their performance during the last six months:

Location Amount of cereal milled Income

$\begin{array}{lcc}\text { Gambiri } & 48,045 \mathrm{~kg} & \text { Rs. } 8,885 \\ \text { Shamakat } & 80,314 \mathrm{~kg} & \text { Rs. } 21,750\end{array}$

\begin{tabular}{lll}
\hline T O T A.L 128,359 \\
$\mathrm{~kg}$ & $\therefore$ & Rs. 30,635
\end{tabular}

NPO/RRAA, Semianniual Report 1995 
Total expenses in the past six months made up $42.2 \%$ of the actual budget of the program.

\section{FARM MECHANIZED STATION:}

It was planned to assist 50 small, vulnerable farmers, 25 in Laghman and 25 in Nangarhar, with tractor services, seeds, fertilizer, pesticides, thresher, and so forth at subsidized prices. A survey was conducted in Sürkh road district, Nangarhar and 25 needy farmers were selected for the program. The participants, who belong to Qala Maroof, Merzä Khail, Sultan Pur, and Sawati villages, will be working as groups. Total amount of land belonged to these farmers were 61 Jeribs.

As a result of another survey, carried out in Alishing, Laghman, 25 vulnerable farmers were selected. The farmers, who are residents of Pass Kelai, Sabar Abad, Deh Gazi, Qali Khan, Islamabad, and Kardi villages, will be working as groups. Total land of these farmers amount to 98 Jeribs.

The farmers were identified jointly by the program staff and the community groups. Agreements, prior to the cultivation of land, were signed with individuals to ensure $50 \%$ contribution from the farmers. The agreement puts emphasis on the point that the farmer must not cultivate narcotic products. During the last six months the land of the participants were plowed at half of the market rate, i.e., Afs.6,000 per Jerib; and necessary fertilizers were provided. Total expenses in the past six months made up $61.3 \%$ of the actual budget of the program.

\section{POULTRY PROGRAM}

This program has been consisted of two projects:

\section{A. POULTRY TRAINING PROJECT \\ B. POULTRY PRODUCTION PROJECT}

\section{A. POULTRY TRAINING RPOJECT}

A Poultry training farm was established in Kunar province in 1990 which was transferred to Nangarhar province in March 1995. The farm was consolidated with the poultry production farm, established in Darontah, Jalalabad in May 1994. The reason for this merging was to provide conditions for the both programs to mutually support each other.

The farm was devised:

- to provide poultry training for the disabled, vulnerable, jobless repatriated people of Nangarhar and Laghman provinces.

to produce good quality feed for chicks, both inside the farm and the chicks raised by the graduates of the program who established poultry farms in their villages.

to produce three months old chicks to be distributed to the small farms of the graduates established in' different villages of above mentioned provinces.

- to produce eggs, both for hatching and personal consuption 
In 1995, it was planned to train 50 persons through poultry training program in two rounds' of three-month courses.

A Survey was carried out in March 1995 in Laghman and Nangarhar provinces to identify trainees for the first poultry training course. Out of 60 persons interviewed, 34 were selected for the first poultry training course. Another survey was carried out in June 1995 in Laghman and Nangarhar, as aresult of which 16 persons, out of 31 interviees were selected for the second course starting on July 10th. The first training course was started on April first and completed at the end of June 1995. Totally, 34 trainees were enrolled in this course, The trainees attended classes five days a week, six hours, 3 hours theoretical and 3 hours practical lessons, per day for three months. The teaching materials were enriched by audiovisual materials such as charts, tables and pictures of sick chickens.

From the first course of poultry training, 34 persons were graduated. Ethnic composition of the graduates showed $20 \%$ Tajick, $2 \%$ Pashai and $78 \%$ pushtoon. All of them were Sunni Muslims. About $25 \%$ of them were married. The average size of their families were between 7-8 persons. About $50 \%$ of them were repatriated from Pakistan to Afghanistan, $12 \%$ of them were displaced. 2 of them were disabled (one with both feet lost and the other with one feet lost). The rest of them were normal; jobless residents of the villages. Out of 34 graduates, half of them were from Nangahar and the other half from Laghman province.

In addition to performing the above mentioned activities, the following items were also purchased and were made ready for distribution to the graduates of 1995

The items purchased for distribution on 34 trainees of 1995

\begin{tabular}{||l|l|l|}
\hline Name of items purchased & Amount or No purchased & Cost of each item purchased \\
\hline \hline Drinkers & 100 & Rs. 4,500 \\
\hline Feeders & 100 & Rs. 7,000 \\
\hline Fence screen & 400 meters & Rs. 8,000 \\
\hline Feeds ingredients & $25,000 \mathrm{~kg}$ & Rs. 175,000 \\
\hline Cement & 250 bags & Rs. 65,000 \\
\hline Medicine & Required & Rs. 49,000 \\
\hline Total Cost & & Rs. 308,500 \\
\hline
\end{tabular}

\section{Distribution:}

In the past six months, each of the 19 graduates of 1994 who established his own poultry, farm in Laghman and Nangarhar provinces were given the following item at subsidized prices:"

\begin{tabular}{||l|l|l||}
\hline Name of items given to them & Amount or No. given $v$ & Cost of each iem . \\
\hline \hline Feeds mixture & $500 \mathrm{~kg}$ & Rs. 3,500 \\
\hline Feeders & 2 & Rs. 140 \\
\hline Drinkers & 2 & Rs. 90 \\
\hline Cement & 5 bags & Rs. 1,300 \\
\hline
\end{tabular}




\begin{tabular}{|c|c|c|c|}
\hline Name of items given to them & Amount or No. given & Cost of each item & \\
\hline Fence screen & 10 meters & Rs. 180 & \\
\hline Chicks & 50 unit & Rs. 1,500 & $\because$ \\
\hline$T \circ a_{t}=1$ & & Rs. 6.710 & \\
\hline
\end{tabular}

\section{Monitoring:}

During the past 6 months 38, trainees' farms, established in Kunar province in 1994, were monitored twice; first, from January 13-14, and the second time on June 18 .

During the first monitoring it was observed that their three months old chicks were vaccinated. Proper medicine, and needed advice about safeguarding their farms against infectious; noninfectious and nutritional deficiencies diseases, were given to them. Out of the 38,17 had 100 , three months old, chicks each while, each of the remaining 21 had 50, three months old, chicks in his farm. Their chicken were generally, in good condition but they had some losses, too. They were helped in vaccination against Newcastle and Gambero diseases and were given the medicines for the treatment of respiratory diseases, leukosis, pullorum, coccidioses and cannibalism at subsidized prices. .

During the second monitoring it was found that out of 38 farms, 30 were still operating and. only 8 were gone out of business. From the 30 farms existed in Kunar province, 11 of them were in good condition, because the chicken were well fed and vaccinated on time. These farms had about 50 chickens, each. The average daily income of an individual farm owner with 25 chicken was equivalent of Afs.6,800; while, the average daily income of those with 50 chicken was Afs. 3,400 . Total expenses in the past six months made up $38.5 \%$ of the actual budget of the fàrm.

\section{B. POULTRY PRODUCTION PROJECT}

During the past 6 months of 1995, 3,100 three months old chicks were produced in the farm. 1,260 of these chicks were distributed to the last year's graduates, 210 of them were sold in the rural area, because of not having enough room to keep them longer, 287 of them were" kept in the farm for development of mother stock, the remaining 1,343 was distributed to the graduates of 1995 . The following table graphically exhibits this activity:

\begin{tabular}{|l|c|c|c|c|}
\hline $\begin{array}{l}\text { No. produced } \\
\text { graduates }\end{array}$ & $\begin{array}{l}\text { No distributed on } 94 \\
\text { go. sold }\end{array}$ & $\begin{array}{l}\text { No. kept as } \\
\text { mother stock }\end{array}$ & $\begin{array}{l}\text { No, distributed on } 95 \\
\text { graduates }\end{array}$ \\
\hline 3,100 & 1,260 & 210 & 287 & 1,343 \\
\hline
\end{tabular}

In addition to the 3100 chicks produced during the past six months, 8,931 eggs were produced, as well. Total income from the sale of chicks and eggs were Rs.98,931.

\section{Note:}

The selling price of the eggsiand chicks were determined by the selling committee members. The eggs were sold on $50 \%$ subsidy of local market price on the communities children who suffered from nutritional deficiencies diseases. 3000 eggs were used for incubation in 
production farm and 6,000 of them which were not suitable for incubation because of their small seizes were sold through medical clinics on children of Hesar Shahi camp who had certificate of malnutrition from the camp clinic.

Beșides these, 19.04 tones of feeds mixture of good quality was prepared from previously purchased feeds ingredients. From the above mentioned amount of feeds mixture 10.5 tones of it was distributed to the 19 trainees who graduated in 1994 from Nangarhar and Laghman provinces and the rest of it was fed to the chicks and chicken of production farm.

The chicks and chicken of production farm were vaccinated 9 times with New castle and Gabbro vaccines, while the chicken were vaccinated only two times with new castle vaccine. The chicken house was sprayed and disinfected once, while the brooder and incubation rooms were disinfected and sprayed three times with disinfectant and insecticides. Total expenses in the past six months made up $44 \%$ of the actual budget of the farm.

\section{PROBLEMS :}

During the past 6 months JRO faced the following problems:

* The female program activities has been stopped by Nangarhar Jehadi shura since May 28, 1995 which causèd a delay in the female programs activities. ACBAR has established a contact committee to work the matter out with the Jehadi Council of Jalalabad. NPO/RRAA is a member of this committee.

* Some unknown, armed people broke into the regional office on 15/16 June, 1995 and took away some cash and non-cash property of the office. No clue has so far been found about the burglars.

*

In another incident, a double cabin Toyota pickup of JRO on its way from Jalalabad to Laghman was hijacked by some armed men, on 28/6/95 at 3:30 pm near Jalalabad University. Search operations through both, official and non-official channels have been launched with no clue as yet found. 


\section{MAZAR REGIONAL OFFICE}

Located in the city of Mazar, Mażar Regional Office (MRO) conducts operations both in Balkh and Baghlan provinces. During the year, Balkh and part of Baghlan was controlled by a coalition of various military groups called the Supreme Coordination Council of the Republic of Afghanistan, represented in the region mainly by the National Islamic Movement of Afghanistan, led by Gen. A. Rashid Dostum. The project activities resumed in February 1995 and continued without any major security problem. The region has followed the plans and policies set by the leadership of NPO/RRAA and tried to adopt them with the specific working conditions of the region. Fruitful ties have been established with the local authorities, other NGO's and the UN agencies, particularly with WFP and UNDP/OPS. A contract of cooperation was signed with the Public Utilities Department of Pulekhumri to secure their cooperation in the rehabilitation of Dahna Ghori road.

The annual budget of MRO for the year 1995 was Rs. $10,320,000$ which made up about $20.1 \%$ of the NPO/RRAA's annual budget. The office spent Rs.3,095,000 during the first six months of the year which is $30 \%$ of its annual budget. Due to the late approval of the project, 28.2.95, the activities and expenses in the first half of the year reflect a smaller percentage than those in the second half of the year. MRO run the projects with a total of 41 staff, $16.3 \%$ of total NPO/RRAA's staff.

CASH FLOW SUMMARY

(All fig. in Pak. Rupees)

\begin{tabular}{|l|l|l||}
\hline \hline BUDGET & EXPENSES & BALANCE \\
\hline $10,320,000$ & $3,095,000$ & $7,225,000$ \\
\hline
\end{tabular}

Mazar Fiegional Office implemented the following programs and projects in the past six months:

1. Income Generation program for disabled male

2. Income Generation program for female

3. Loan Scheme project

4. Construction program

5. Road Rehabilitation program

6. Water Supply program

7. Farm Mechanized Station program

8. Irrigation program

9. Energy Production project

\section{INCOME GENERATION PROGRAM FOR DISABLED MALE}

The program provides skills training and/or tools for the vulnerable disabled men in the rural areas of Balkh and Baghlan provinces. A total of 41 disabled ( a little over $100 \%$ of the annual target) have been identified and organized in mobile, short term (4 - 6 months) training courses. Identification of the trainees and type of courses were made in cooperation and consultation with the local communities. 
In February 1995, the program conducted surveys in Dawlatabad (Balkh) and Pulekhumri (Baghlan), and identified 22 eligible disabled men to be trained in various skills in mobile; courses. The following table provides information about the courses:

\begin{tabular}{|c|c|c|c|c|c|c|}
\hline \multirow[t]{2}{*}{ No. } & \multirow[t]{2}{*}{ Courso Titlo } & \multicolumn{3}{|c|}{$100 \cdot 1 / \circ$ r } & \multirow[t]{2}{*}{ \# Trainees } & \multirow{2}{*}{ datarting } \\
\hline & & Village & District & Province, & & \\
\hline 1 & Embroidery & . Qarchigak & Dawlatabad & Balkh & 4 & $5 / 95$ \\
\hline 2 & Kelim weav. & Deh Rubat & Dawlatabad & Balkh & 4 & $5 / 95$ \\
\hline 3 & Tailoring & Hayratan & Dawlatabad & Balkh & 5 & $5 / 95$ \\
\hline 4 & Kelim weav. & Husainkhil & Pulekhumri & Baghlan & 9 & $5 / 95$ \\
\hline & $\begin{array}{lllll} & 0 & \mathbf{a} & \mathbf{a}\end{array}$ & 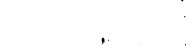 & & & 22 & \\
\hline
\end{tabular}

Regular monitoring of the courses have been carried out and work is going on according to the plans.

A second survey was conducted in different villages of Pulekhumri, Kelagai. (Baghlan), and Dawlatabad, as a result of which, 19 disabled were selected and organized in various skills training courses. The following table furnishes information about the courses:

\begin{tabular}{|c|c|c|c|c|c|c|}
\hline \multirow[t]{2}{*}{ No } & \multirow[t]{2}{*}{ Course title } & \multicolumn{3}{|c|}{ to a 10 n } & \multirow[t]{2}{*}{ \# Trainess } & \multirow{2}{*}{ sterting } \\
\hline & & Village & District & Province & & \\
\hline 1 & Embroidery & Qaradaka & Kelagai/Doshi & Baghlan & 4 & $7 / 95$ \\
\hline 2 & Carpet weaving & Chelkapa & Kelagai/Doshi & Baghlan & 4 & $7 / 95$ \\
\hline 3 & Leather-bag making & Maktab & Kelagai/Doshi & Baghlan & 4 & $7 / 95$ \\
\hline 4 & Radio repairing & Bedo. ': & Dawlatabad & Balkh & 3 & $7 / 95$ \\
\hline 5 & Tailoring & Qul Taq & Dawlatabad & Balkh & $4 \ldots-\cdots$ & $7 / 95$ \\
\hline & T o t a $1-$ & $\because$ & & & 19 & \\
\hline
\end{tabular}

Tools and equipment will be provided for the graduates of the courses on a $50 \%$ subsidized loan basis which will be repaid within 18 months. Regular monitoring and follow up will be carried out to assist the participants during and after training, and to evaluate the impact of the program on the lives of the participants. The expected impact of the program is creation of an average income of Rs. 35 per day for the 40 participating disabled men, and helping them to become active and productive members of the society. The community contributed in two different forms: providing rooms for training courses and safeguarding the tools and; equipment of the courses. Total contribution came up to an equivalent of Rs.17,600. Total expenes of the program made up $28.3 \%$ of its actual budget.

\section{INCOME GENERATION PROGRAM FOR WOMEN}

The program provides skills training and tools for vulnerable women in the rural areas of: Balkh and Baghlan provinces. A total of 88 women (110\% of the annual target) have been identified and organized in mobile, short term (4-6 months) training courses. Identification 
of the trainees and selection of the type of courses were made in cooperation and consultation with the local communities.

In February 1995, the program conducted a survey in Dawlatabad (Balkh), as a result of which, 37 eligible women were identified to be trained in various skills in mobile short term (4 - 6 months) courses. The following table provides information about the courses:

\begin{tabular}{|c|c|c|c|c|c|c|}
\hline \multirow[t]{2}{*}{ No. } & \multirow[t]{2}{*}{ Course Title } & \multicolumn{3}{|c|}{ Locat on } & \multirow{2}{*}{ Trainees } & \multirow{2}{*}{$\begin{array}{l}\text { starting } \\
\text { date }\end{array}$} \\
\hline & & Village & District & Province & & \\
\hline 1 & Embroidery & Charbagh Sayedan & Dawlatabad & Balkh & 5 & $5 / 95$ \\
\hline 2 & Kelim weaving & Qarchigak & Dawlatabad & Balkh & 7 & $5 / 95$ \\
\hline 3 & Kelim weaving & Surkh Gunbad & Dawlatabad & Balkh & 10 & $5 / 95$ \\
\hline 4 & Kelim weaving & Dawlatabad & Dawlatabad & Balkh & 7 & $5 / 95$ \\
\hline 5 & Carpet weaving & Nakhshirabad & Dawlatabad & Balkh & $\because$ & $5 / 95$ \\
\hline & $T$ o t a 1 & . & & & 37 & $\because$ \\
\hline
\end{tabular}

All the courses are running properly except for the carpet weaving course that was cancelled because the participants did not accept the NPO/RRAA's policies.

A second survey was conducted in Dawlatabad, Pulekhumri, and Kelagai in the month of. June. Fifty one women were selected to be organized in various courses in the month of jully. The participants belong to Pushtoon, Tajik, Hazara, Uzbek and Turkman ethnic groups.

The following table exhibits details of the courses:

\begin{tabular}{|c|c|c|c|c|c|c|}
\hline \multirow[t]{2}{*}{ No. } & \multirow[t]{2}{*}{ Course Title } & \multicolumn{3}{|c|}{ Locat 0 n } & \multirow{2}{*}{ Trainees } & \multirow{2}{*}{$\begin{array}{l}\text { starting } \\
\text { date }\end{array}$} \\
\hline & & Village & District & Province & & \\
\hline 1 & Embroidery & Shabuddin & Pulekhumri & Baghlan & 5 & $7 / 95$ \\
\hline 2 & Kelim weaving & Masjid Ranga & Dawlatabad & Balkh & 5 & $7 / 95$. \\
\hline 3 & Kelim weaving. & Gowsawaran & Pulekhumri & Baghlan & 9 & $7 / 95$ \\
\hline 4 & Kelim weaving & Qaradaka & Kelagai/Doshi & Baghlan & 11 & $7 / 95$ \\
\hline 5 & Carpet weaving & Chekapa & Kelagai & Baghlan & 8 & $7 / 95$ \\
\hline 6 & Embroidery & Maktab & Kelagai & Baghlan & 5 & $7 / 95$ \\
\hline 7 & Carpet weaving & Qarchigak & Dawlatabad & Balkh & 8 & $5 / 95$ \\
\hline & $\begin{array}{ccccc}T & 0 & t & a & 1\end{array}$ & & & & 51 & \\
\hline
\end{tabular}

Tools and equipment will be provided for the graduates of the courses on a $50 \%$ subsidized, loan basis which will be repaid within 18 months. Regular monitoring and follow up will be carried out to assist the participants during and after training, and to evaluate the impact of the program on the lives of the participants. The expected impacts of the program are creating an average daily income of Rs. 30 for the 80 participating vulnerable women, helping them to become active and productive members of the community, and to assume greater 
socio-economic role in the society. Community contribution was in the form of provision of rooms for the courses, and safeguarding the tools and equipment of the courses, which amounted to an equivalent of Rs.21,600. Total expenes of the program made up $20.7 \%$ of its actual budget.

\section{LOAN SCHEME PROJECT (ongoing)}

As an experiment the project was designed to assist vulnerable skilled men, women and vulnerable owners of small enterprises through offering small loans repaid in monthly installments within twelve months. The project extended its services to a total of 81 people including 67 skilled women and 14 men, during 1994. The female participants consisted of Kelim weavers, carpet weavers, and woolen thread spinners. The skills supported through assisting the male participants were tailoring, vegetable oil producing, carpentry and sweet making.

In 1995, no new' loans were granted. Activity of the project for this year was limited to collecting the installments and providing assistance and instruction for the participants. All the participants repaid their dues which amounted to Rs.57,000.

\section{CONSTRUCTION PROGRAM}

The program consisted of two projects:

\section{A. Rehabilitation of Dawlatabad veterinary clinic \\ B. Rehabilitation of Rabia Balkhi high school}

\section{A. REHABILITATION OF DAWLATABAD VETERINARY CLINIC}

Work on the clinic began on 19/4/95 and completed in June. The clinic, according to a previously signed agreement with the District Shura of Dawlatabad, was handed over to the veterinary section of the Provincial Department of Agriculture of Balkh province that will be responsible for the maintenance and running of the clinic.

About 27 villages including 2300 families benefit from this clinic, where 15 to 20 animals are examined per day. Vaccination teams from the clinic pay regular visits to the neighboring villages to render necessary services. Beneficiaries of the clinic belong to Turkman, Uzbek; Tajik, Pushtoon, and Hazara ethnic groups. Two doctors, five vaccinators, and one chowkidar got jobs after the clinic became operational. The medicine and other necessary materials for the clinic are being provided by FAO. Expected impact of the project is decrease of animalrelated and animal diseases in the area which will lead to the low moitality and morbidity rate among the domestic animals, and increased income level of the villagers. Community contribution were equivalent of Rs.5,560 in the form of free labor (139 man-day work).

\section{B. REHABILITATION OF. RABIA BALKHI HIGH SCHOOL}

This high school is located in Dawlatabad district of Balkh province. Rehabilitation work on the school started in May 1995. Before the work began, an agreement regarding community, contribution was signed with the district rehabilitation Shura, through which they pledged to provide eight unskilled workers every working day till completion of the project, as well as, group labors on some particular occasions. Up to date, 199 man-day work have been contributed by the community which is equivalent of Rs.7,960. $75 \%$ of the construction work 
have so far been completed.' By completion of the school building, 540 girls from 2,000 families will get education; and, one principal, 21 teachers, 2 chowkidars; and one store keeper will secure jobs.

Total expenes of the program made up 51.6\% of its actual budget; and actual share of the community formed $34 \%$ of the original plan.

\section{ROAD REHABILITATION PROGRAM}

This program contains the following four projects:
A. Rehabilitation of Dahna Ghori road
B. Construction of three bridges in Shahabuddin village
C. Reconstruction of $\mathbf{3 7}$ culverts on Dawlatabad - Siagird road
D. Construction of Shikh"Jalal bridge

\section{A. REHABILITATION OF DAHNA GHORI ROAD}

The project repaired $19 \mathrm{Km}$ road from Pulekhumri to Dahna-e-Ghori from $21 / 11 / 94$ to $8 / 6 / 95$ The work done on the road included leveling, graveling, gradering of $19 \mathrm{Km}$ road; digging the ditches on both sides of the road; constructing two bridges, each $8 \mathrm{~m}{ }^{*} 4 \mathrm{~m}$, and two washes; fixing of six culverts from reinforced concrete pipes.

Before the project started, an agreement was signed with the local people to ensure their contribution to the project. Another agreement was signed with the Department of Public Utilities (DPU) and the local authorities according to which DPU would provide machineries and dump trucks while NPO/RRAA Mazar would only assume the costs of fuel, oil and repairing of the vehicles and machineries. The following table shows the gross amount of community contribution in its different forms:

\begin{tabular}{|c|c|c|c|c|c|c|}
\hline $\begin{array}{l}\text { Type of work or } \\
\text { materials }\end{array}$ & amount & 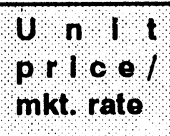 & $\begin{array}{l}\text { Unit pricel } \\
\text { opu rate }\end{array}$ & $\begin{array}{l}\text { Total price in } \\
\text { market rate }\end{array}$ & $\begin{array}{l}\text { Total price In } \\
\text { DPU's rate }\end{array}$ & Gontribution \\
\hline Leveling & $19,900 \mathrm{~m}^{3}$ & . $\quad 10$ & 5 & 199,000 & 99,500 & 99,500 \\
\hline graveling : & $33250 \mathrm{~m}^{3}$ & .75 & 24 & $2,490,000$ & 798,000 & $1,692,000$ \\
\hline gradering & $33,250 \mathrm{~m}^{3}$ & 8 & 4 & 266,000 & 133,000 & 133,000 \\
\hline masonry stone & $250 \mathrm{~m}^{3}$ & $\because 200$ & 0 & 50,000 & 0 & 50,000 \\
\hline $\begin{array}{l}\text { digging of the } \\
\text { ditches }\end{array}$ & $5,000 \mathrm{~m}^{3}$ & $\because 10$ & 3 & 50,000 & 15,000 & 35,000 \\
\hline $\begin{array}{l}\text { concrete plates } \\
\text { \&pipes }\end{array}$ & $18.4 \mathrm{~m}^{3}$ & 4,000 & 3,000 & 73,600 & 55,200 & 18,400 \\
\hline $\begin{array}{lll}T & O & T\end{array}$ & A $L$ & .. & & $3,128,600$ & $1,100,700$ & $2,027,900$ \\
\hline
\end{tabular}

To find out the actual community contribution, the expenses related to the fuel, oil, maintenance of vehicles and machineries, labor wages and raw materials, shared by the NPO/RRAA, Mazar, and are part of the total gross contribution must be deducted from this figure. Hence, the actual community contribution was: 
Total gross contribution of DPU

Total costs of NPO/RRAA, Mazar for fuel, oil, labor wage, raw mätérials; repairing

Total Actual Community Contribution

$$
=\text { Rs. } 2,027,900
$$

$=$ Rs. $1,043,174$

$$
=\text { Rs. } \underline{\underline{984,726}}
$$

The project's planned community contribution were Rs. 100,000 while the actual community contribution turned out to be $984 \%$ of it. Provision of heavy machineries and dump trucks at á low cost, provision of cement, pre-cast reinforced concrete pipes and plates for the culverts and bridges at subsidized prices," and supply of masonry stone for free were various forms of contribution made by the local community and the local authorities. Therefore the actual expenses of the Mazar regional office for this project fell below the original budget. The reason was the unforeseen high potential of community contribution which was almost 10 times of the planned figure. WFP Mazar, as well, under its Food for Work program, contributed to the project an amount of $5,967 \mathrm{mt}$. wheat which were equivalent of $8,354 \mathrm{US}$ dollars or 250,614 Pak. rupees.

More than 15,000 families, comprising 90,000 inhabitants of 153 villages of the district, will benefit from this road. The residents include Tajik, Pushtoon, Uzbek, Hazara, which.represent various sects of Islam such as Sunni, Shiaite, and Ismailie.

Construction of the road had an obvious impact on the economic betterment and growth of ${ }^{-}$ the local community. Transportation fare of both, personnel and goods, decreased by $30 \%$; and the number of vehicles carrying goods and people, and the amount of trade from Dahna to Pul-e-khumri increased after the road was rebuilt. Moreover, travelling time between the two destinations decreased which help the travellers save lots of time. While the project was ending some other NGO's took interest in working in Dahna and started rehabilitating the school and health clinic of the district as the road facilitates transportation to the area. Total expenes of the project made up $54 \%$ of its actual budget.

\section{B. CONSTRUCTION OF THREE BRIDGES IN SHAHABUDDIN VILLAGE}

Construction of these bridges that are located in Pulekhumri district, started on 28 March 1995. The dimensions of two of them are $5 \mathrm{~m} * 4 \mathrm{~m}$ each, and those of the third one are $6 \mathrm{~m}$ * $5 \mathrm{~m}$. Five villages with a total of 15,000 inhabitants will benefit from these bridges.

One of the bridges have been completely finished, and $45 \%$ work of the other two have been fulfilled, so far. Due to söme irrigation problems the villagers requested the project to be halted till the end of the irrigation period. The work was stopped and will be resumed after the period is over. The project will facilitate transportation of agricultural products to the district market and will decrease the fare of trucks and buses by $30 \%$. The community contributed 6 un-skilled workers per day which amounted to some Rs.4,500.

\section{CONSTRUCTION OF 37 CULVERTS ON DAWLATABAD - SIAGIRD ROAD}

This project is to build 26 pipe culverts and 11 arch culverts on the road connecting Dawlatabad to Siagird, Balkh province. Activity of this project started in May 1995. So far 249 concrete pipes that make up $14.7 \mathrm{~m}^{3}$ reinforced concrete materials, have been produced. Excavation of six culverts $(7 * 1 * 2 \mathrm{~m})$ has been completed. In total, $25 \%$ of the project work has been finished. 
Construction of the mentioned culverts will solve transportation problems of 10 villages with an estimated population of 23,000 people.

\section{CONSTRUCTION OF SHIKH JALAL BRIDGE}

shikh Jalal village is located on the road between Nahrin and Shahre Jadid, Baghlan:Considering the general traffic load in the area, this road is heavily used by buses and trucks. The bridge in Shikh Jalal was damaged during the war. Construction of the bridge $(7 * 4 * 4 \mathrm{~m})$ was started in June 1995. So far, the excavation and stone masonry of the foundation and wing walls have been finished and is ready for mounting the slabs. The slabs that will be purchased from Pole Plant in Pulekhumri have high quality and are less expensive. Construction of the bridge will solve transportation problems of the travellers between Nahrin and Baghlan. Since the Salang highway has been blocked for over one year now; the travellers from Badakhshan, Takhar, Kunduz, and Baghlan are using this bridge to reach Kabul. All residents of Nahrin district, 180 villages with 17,000 families, will benefit from the bridge. Community contribution was in the form of free labor, equivalent of Rs.8,500, and cash for the laborers, an amount of Rs.6,000 that totaled to Rs. 14,500 .

Total expenes of the projects described under "B", "C", and "D" made up 54\% of their total actual budget, while the actual share of community to these projects formed $23.7 \%$ of the original plan.

\section{WATER SUPPLY PROGRAM}

Providing concrete rings for the shallow wells of 150 vulnerable families, and 150 sand filters for another 150 vulinérable families; and construction of a water reservoir have been targets: of the program for the current year. The program is aimed at provision of safe and healthy drinking water for the vulnerable families and rural communities in Balkh and Baghlan provinces.

Activities of the program covered Nahrin, Pulekhumri, and Dawlatabad districts and the following were carried out:

A. Concrete Rings: Production of concrete rings was started in Dashti Khoja Alwan, Pulekhumri district on 24/4/95, and 420 rings were produced. Out of this number, 60 were: distributed among six families. Producing concrete rings in Dawlatabad district was started in June 1995. 200 rings were produced out of which 104 were distributed to 8 deserving families in Dawlatabad.

The concrete rings will enable the assisted families to get access to safe and clean drinking water and their wells will endure longer. Community contribution for this activity was Rs. 27,281 that was paid in the form of the $50 \%$ subsidized price of the rings.

B. Transferring of water from a spring to a village: This spring has been situated in Totak village of Burka district, Baghlan. Work on this spring started on 1/5/95 and was completed in the end of May, 1995. The project was handed over to the community. 150 families consisted, of 1200 people will benefit from this piping system. The community contributed 204. man-day work free of charges, an estimated value of Rs.12,500.

C. Shikh Jalal reservoir: Work started in the month of June. Preparing construction materials, signing of the agreement with the local community and local authorities regarding 
their contribution, have been done so far. Around 600 families, 2400 persons and their animals will have access to safe drinking water. The community contributed, in the form of unskilled labor, an equivalent of Rs.7,800,

Total expenes of the program made up $47.5 \%$ of its actual budget. Actual community contribution to the program formed $47.5 \%$ of the oringinal plan.

\section{FARM MECHANIZED STATION}

A. new policy was set for the NPO/RRAA's farm mechanized stations according to which, some $\mathbf{5 0}$ vulnerable small farmers were to be carefully identified, and organized in groups. These framers were going to be assisted by different services such as plowing, providing seeds, fertilizers, pesticides, harvesting, and transporting of their products to the market at: subsidized prices.

The program which started in April 1995, will be continued to end of March 1996. The following work have been performed in the past three months:

1. 50 Jeribs of land, properties of seven small farmers, have been plowed at a subsidized price, in Aliabad Chishma Sher village, Pulekhumri district.

2. $4,046 \mathrm{~kg}$ wheat have been threshered in Aliabad Chishma Sher which brought an income of $234 \mathrm{Kg}$ wheat to the program.

3. 11 Jeribs of land, properties of 24 small farmers, were plowed in Dawlatabad district.

Vulnerable farmers were identified jointly by the staff and community groups: $A$ total of Rs.27,000 net income was earned by the program from plowing and threshering services performed. The bulk of the activities will be performed in the fall and spring, the plowing and harvesting seasons.

In the first two months of the year, the program continued activities left from 1994 plan as its duration was till the end of 1994. 920 Jeribs of land that belonged to 147 small farmers were plowed during this time. Achievements of the program for the 1994 were $121 \%$ in terms the of number of farmers assisted, and $103 \%$ in terms of the amount of land plowed. Under the 1994 plan, a total of 3500 Jeribs of land were plowed that belonged to 605 small farmers.

In regard with the conditions of the program services for the vulnerable farmers it is needed to mention that an agreement, prior to the cultivation of land, is signed with individuals to ensure $50 \%$ contribution from the farmers. The agreement puts emphasis on the point that the farmer must not cultivate narcotic products. Regular monitoring, by the staff of the project, will be done to ensure community participation and quality of work. The farmers not complying with the agreement will, according to the agreement, be responsible to pay the subsidized amount covered by the project, and the project implementation will be banned in those areas. Total expenes of the program made up $37.7 \%$ of its actual budget. Actual community contribution to the program formed $16 \%$ of the oringinal plan.

\section{IRRIGATION PROGRAM}

This program consists of the following three projects:

NPO/RRAA, Semiannual Roport 1995 

A. Construction of three aqueducts;
Construction and cleaning of Aqchesma spring
B. Construction of spillway \& cleaning of Gowhargan canal

\section{A. CONSTRUCTION OF THREE AQUEDUCTS}

This project is located in Quzi, Taba Shakh, and Noorak villages of Nahrin district, Baghlan. Construction work of the aqueduct in Noorak village was completed from 24/5/95 to 16/6/95. This aqueduct facilitates transmission of irrigation and drinking water to four villages, including Noorak village, that constitute 400 hectares of land and 200 farmer families. The project impact is irrigation of 640 hectares of land that belong to 390 farmers. Furthermore, 20\% increase in the production of crops is expected. The villagers contributed 9 unskilled workers every working day from the start to the end of the project. Besides, they contributed six timbers for the frames of the viaducts. Total community contribution amounted to an equivalent of Rs.37,700.

Construction of the aqueduct in Quzi village started in the month of June. Stone and sand were transported to the site, and 49 cubic meters foundation have been excavated.

Raw materials have been transported to the site for Taba Shakh aqueduct and Aqchastima spring. Construction work will begin in July.

\section{B. CONSTRUCTION OF SPILLWAY \& CLEANING OF GAWHARGAN CANAL}

The initial survey for cleaning of Gawhargan canal and construction of its Spillway was carried out by MRO, NPO/RRAA. However, due to lack of coordination among the aid organizations in the area, the cleaning work' 'n this canal was undertaken by German Agroaction. MRO is going to submit a proposal for cleaning of Ajmir Khord canal, instead.

Total expenes of the program made up $28.7 \%$ of its actual budget. Actual community contribution to the program formed $25.3 \%$ of the oringinal plan.

\section{ENERGY PRODUCTION PROJECT}

The project was started as an experiment to study the possibility of producing bio-gas from the manure of domestic animals on a household level. However, the result of work which had been started in P.ulekhumri" showed that the climate in the North is not suitable for implementing such projects. A detailed report later on will be submitted in this regard. Total expenes of the project made up $24.9 \%$ of its actual budget. 


\section{PAKISTAN PROGRAMS}

Programs carried out in Pakistan were directly linked to and supervised by the Central Office: Pakistan programs were being implemented in refugee camps, NWFP, and in Peshawar City (only those neighborhoods where the most vulnerable, new arrivals from Kabul reside).

The programs implemented in Pakistan during the past six months are as follows:

\section{Income Generation Program for Female}

2. Income Generation program for Disabled Male

\section{INCOME GENERATION PROGRAM FOR FEMALE}

This program consisted of two components:

a. Free Training and/or Tools for Refugee Women

b. Small Loans Scheme

\section{a. Provision of Skills Training and/or Tools}

A total of 203 (80\% of the total target) needy, skilled and un-skilled women were identified as eligible individuals for assistance in refugee camps and the residents of the new arrivals from Kabul, in NWFP and Kurram Agency. This was done through or in cooperation with the Social Welfare Cell (SWC) of the Commissionerate for Afghan Refugees (CAR). Preference was given to the neediest female headed households. Out of the 203 participants, 170 were unskilled and the remaining $\mathbf{3 3}$ were skilled women. The unskilled women were organized in 16 mobile courses to receive training in carpet weaving, knitting, ornamental plaiting, engraving, soap making, and chalk making. 13 centers have already been established, however, the remaining three [\#12, 13, 14 table below] will be opened in August. The graduates will be provided free toobls and equipment of the skills learned. The table below exhibits details of the courses:

\begin{tabular}{|c|c|c|c|c|c|c|}
\hline \multirow[t]{2}{*}{ No } & \multirow[t]{2}{*}{ COURSE TITLE } & \multicolumn{2}{|c|}{ LOCATION } & \multirow{2}{*}{$\begin{array}{l}\text { NO T } \\
\text { RAIA } \\
\text { NEES }\end{array}$} & \multirow{2}{*}{$\begin{array}{l}D A E \\
S T A R T E D\end{array}$} & \multirow[t]{2}{*}{ DURATION } \\
\hline & & CAMP & DISTRICT & & & \\
\hline 1 & Carpet Weaving & Jalozai & Pesh.ll & $22^{\star}$ & 4.95 & 6 Months \\
\hline 2 & Knitting & Baraget & Pesh. & 8 & 4.95 & 5 Months \\
\hline 3 & Ornamental Plaiting & Naser Bagh & $"$ & $28^{*}$ & 5.95 & 3 Months \\
\hline 4 & Carpet Weaving & Nașer Bagh & $"$ & 10 & 5.95 & 6 Months \\
\hline 5 & Carpet Weaving & Azakhil & Pesha.ll & 10 & 5.95 & 6 Months \\
\hline 6 & Knitting & Naser Bagh & Pesh. & 12 & 5.95 & 5 Months \\
\hline 7 & Carpet Weaving & Akora & Pesh.II & 10 & 6.95 & 6 Months \\
\hline 8 & Special Beads Works & Gharib Abad & Pesh. & 10 & 6.95 & 5 Months \\
\hline 9 & Carpet Weaving & Khurasan & Pesh.l & 10 & 6.95 & 6 Months \\
\hline 10 & Ornamental Plaiting & Zakat Colony & Pesh. & 10 & 6.95 & 3 Months \\
\hline
\end{tabular}




\begin{tabular}{|c|c|c|c|c|c|c|}
\hline \multirow[t]{2}{*}{ NO } & \multirow[t]{2}{*}{ COURSE TITLE } & \multicolumn{2}{|c|}{ LOCATION } & \multirow{2}{*}{$\begin{array}{l}\text { NO.T } \\
\text { RAIA } \\
\text { NEES }\end{array}$} & \multirow{2}{*}{$\begin{array}{l}\text { DATE } \\
\text { STARTED }\end{array}$} & \multirow{2}{*}{ DURATION } \\
\hline & & CAMP & DISTRICT & & & \\
\hline 11. & Engraver ${ }^{\circ}$ & Tahkal & Pesh. & 10 & 6.95 & 5 Months \\
\hline 12 & Soap Making & Zandai & Pesh.II & 10 & $8 / 95$ & 3 Months \\
\hline 13 & Soap Making & Munda & Pesh.I & 8 & $8 / 95$ & 3 Months: \\
\hline 14 & Chalk Making & Khaiwa & Pesh.II & 12 & $8 / 95$ & 3 Months \\
\hline & T O T A L T T & & & 170 & & . \\
\hline
\end{tabular}

\section{*. Two courses}

Tailoring courses have been taken out from the training portfolio of the program as sufficient number of tailors were trained in the past years. This year the program substituted the readymade courses with courses selected and designed with direct participation of the beneficiaries. The goal was to provide wider opportunities for the refugee women to take part in the decision making processes and learn more about the market and small businesses through exchange of ideas.

Out of the remaining 33 skilled women 26 were given tools and equipment in various crafts. Details of the activities are given in the table below:

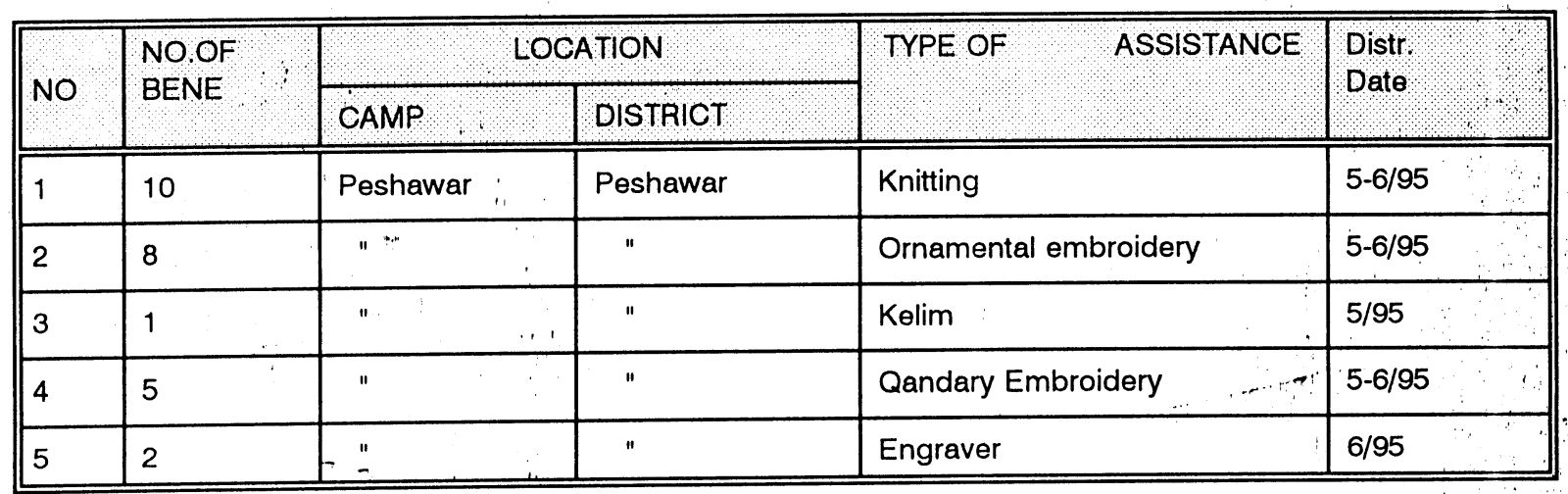

The remaining 7 skilled women identified will receive tools and equipment in July. Activities were designed to enable the beneficiaries to earn an income with their newly acquired skills and equipment. Regular monitoring of the trainees and follow up of the graduates and the skilled women who received tools and equipment were carried out to solve their problems regarding training; marketing, and self-employment. Total expenses of this project for the last six months made up $40.2 \%$ of its total budget.

\section{b. Small Loans Scheme}

Under this scheme, 98 "new arrival" refugee women were assisted with start-up tool kits or/and materials worth of Rs.203,497 through small loans which are to be repaid in installments within 18 months. Total repayments from this year's loans amounted to Rs. 23,191 . The following table provides details of the activities: 


\begin{tabular}{|c|c|c|c|c|c|}
\hline NO. & NOBENE & TYPE OF ASSISTANCE & $\begin{array}{l}\text { AMOUNT } \\
\text { LOANED }\end{array}$ & $\begin{array}{l}\text { AMOUNT } \\
\text { REPAID }\end{array}$ & BAUANCE \\
\hline 1 & 34 & Tailor & 74755 & 16965 & 57790 \\
\hline 2 & 6 & Beans Seller & 12364 & 1720 & 10644 \\
\hline 3 & 11 & Embroidery & 22940 & 2560 & 20380 \\
\hline 4 & 2 & Cook & 4108 & 200 & 3908 \\
\hline 5 & 5 & Zic Zac machine & 15171 & 0 & 15171 \\
\hline 6 & 2 & Mixer & 2880 & 300 & 2580 \\
\hline 7 & 3 & Medical Lab. & 1700 & 0 & 1700 \\
\hline 8 & 34 & Carpet weaver & 64444 & 1446 & 62998 \\
\hline 9 & 1 & Leather works & 2400 & 0 & 2400 \\
\hline 10 & 1 & Yogurt & 2735 & 0 & 2735 \\
\hline Total & \multicolumn{2}{|l|}{98} & 203497 & 23191 & 180306 \\
\hline
\end{tabular}

Regular monitoring of the Loan Scheme was carried out during the past six moths. 64 women who received loans in 1994, repaid $62 \%$ of their dues which indicates effectiveness and profitability of the loans. The following table presents details of the monitoring and repayment reports of the 1994 beneficiaries:

\begin{tabular}{|c|c|c|c|c|c|}
\hline No. & NOBENE. & SKILLS ASSISTED & $\begin{array}{l}\text { AMOUNT } \\
\text { LOANED }\end{array}$ & $\begin{array}{l}\text { AMOUNT } \\
\text { REPAID }\end{array}$ & BAEANCE \\
\hline 1 & 23 & Tailor & 49369 & 36984 & 12385 \\
\hline 2 & 17 & Beans Seller & 37346 & 18196 & 19150 \\
\hline 3 & 5 & Embroidery & 24878 & 9700 & 15178 \\
\hline 4 & 1 & Engraver & 9140 & 3600 & 5540 \\
\hline 5 & 4 & Zic Zac machine & 33160 & 25840 & 7320 \\
\hline 6 & 6 & Ornamental Plaiting & 5860 & 2890 & 2970 \\
\hline 7 & 3 & Soap making & 6272 & 2200 & 4072 \\
\hline 8 & 1 & leather Works & 9880 & 5870 & 4010 \\
\hline 9 & 1 & Knitting $\ldots$ & 1718 & 1662 & 56 \\
\hline 10 & 1 & yogurt ". & 3433 & 3433 & 0 \\
\hline 11 & 1 & Poultry & 3070 & 3070 & 0 \\
\hline 12 & 1 & Carpet weaving & 5331 & 4300 & 1031 \\
\hline Total & 64 & .. & 189,457 & 117,745 & 71,712 \\
\hline
\end{tabular}

Total expenses of this project for the last six months made up $50.2 \%$ of its total budget. 


\section{INCOME GENERATION PROGRAM FOR DISABLED. MALE}

The program provided training and/or tools and equipment of a skill for 136 needy refugee disabled men (54\% of the total target) in Kurram Agency, South Waziristan, and Peshawar areas.

The disabled program activities during the first six months focused on establishing mobile vocational training centers to train unskilled disabled men, providing tools and equipment for the graduated trainees and skilled disabled men, providing shops, push carts, etc. for those disabled men who were not able to be trained in a skill. Criteria for selection of skills and design of training courses were the type of disability of groups/individuals and demands of the market. The disabled program members of staff with the cooperation of S.W.C coordinators and animators have tried to assist the most needy and vulnerable new arrival Afghan refugees.

Out of the 136 participants, 40 were skilled and the remaining 96 were unskilled disabled men. The following table presents the details of the courses established for the unskilled disabled men:

\begin{tabular}{|c|c|c|c|c|c|c|c|}
\hline \multirow{2}{*}{ NO } & \multirow{2}{*}{\multicolumn{2}{|c|}{ COURSE TITLE }} & \multicolumn{2}{|c|}{ LOCATION } & \multirow{2}{*}{$\begin{array}{l}\text { NO.T } \\
\text { RAIA } \\
\text { NEES }\end{array}$} & \multirow{2}{*}{$\begin{array}{l}\text { DATE } \\
\text { STARTE } \\
\text { D }\end{array}$} & \multirow[t]{2}{*}{ DURATION } \\
\hline & & & CAMP & DISTRICT & & & \\
\hline 1 & Embroidery & 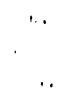 & Enzeri & Kurram Ag. & 10 & $3 / 95$ & $\begin{array}{r}5 \\
\text { Months }\end{array}$ \\
\hline 2 & Embroidery & & Jalozai & Pesh. & 10 & $5 / 95$ & 5 Months \\
\hline 3 & Tailoring & & Enzeri & Kurram Ag. & 10 & $3 / 95$ & 4 Months \\
\hline 4 & Tailoring & & Sadda & Kurram Ag. & 12 & $4 / 95$ & 4 Months \\
\hline 5 & Tailoring, & & Bagan & Kurram Ag. & 10 & $5 / 95$ & 4 Months \\
\hline 6 & Tailoring & & Akora & Kurram Ag. & 10 & $4 / 95$ & 4 Months \\
\hline 7 & Tailoring & $\therefore$ & Khairabad & Kurram Ag. & 10 & $6 / 95$ & 4 Months \\
\hline 8 & Leather Works " & & Jalozai & Pesh. & 10 & $5 / 95$ & 5 Months \\
\hline 9 & Radio Repairing & & Naserbagh & Pesh. & 6 & $3 / 95$ & 6 Months \\
\hline 10 & Carpet Weaving & & Naserbagh & Pesh. & 8 & $5 / 95$ & 6 Months \\
\hline & TO T A L IF & & & & 96 & & \\
\hline
\end{tabular}

The Program intends to increase the number of self supporting disabled Afghan refugees, to provide possibilities for the disabled to contribute in the rehabilitation work and continue earning an income after repatriation.

During the first six months of 199540 needy skilled disabled men were identified and provided tools and equipment of their pertinent skills. The table below provides the details: 


\begin{tabular}{|c|c|c|c|}
\hline No & $\begin{array}{l}\text { NOOF } \\
\text { BENE }\end{array}$ & Location & Skills assisted \\
\hline 1 & 1 & Peshawar & Electrician \\
\hline 2 & 1 & ." & Carpenter \\
\hline 3 & 8 & $\begin{array}{l}\text { Kürram Age. } \\
\text { Peshawar }\end{array}$ & Cigarette seller \\
\hline 4 & 7 & " " & Shoe repairer \\
\hline 5 & 14 & $" \ldots$ & Sandal seller \\
\hline 6 & 7 & $"$ " " & Tailor \\
\hline 7 & 1 & $" \quad "$ & Bicycle repairer \\
\hline 8 & 1 & $\because " \quad "$ & Carpet weaver \\
\hline
\end{tabular}

During the first six months of 1995 out of 160 beneficiaries who were under monitoring schedule, 130 were monitored. Monitoring shows that they were busy using NOP's assisted tools and equipment, their average daily income was over Rs.35. Total expenses of this project for the last six months made up $42.3 \%$ of its total budget. 


\begin{tabular}{|c|c|c|c|c|c|c|c|c|c|c|c|c|c|c|}
\hline onunity support & 480 & 480 & 2037 & 27742.3 & 0 & & 0 & 0 & 0 & 0 & 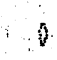 & 0 & 0 & 420 \\
\hline in -Hecha-station & 1091 & 923 & 566 & 35761.3 & 168 & & 0 & 0 & 0 & 1 & 0 & 0 & 0 & 925 \\
\hline j-ijsabled & 648 & 848 & 234 & 414.36 .1 & 0 & & 0 & 0 & 0 & 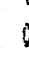 & i) & 0 & 0 & 648 \\
\hline i Feuale & 969 & 969 & 398 & 5714.1 & 0 & & 0 & 0 & 0 & 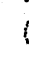 & 0 & 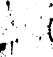 & 0 & 969 \\
\hline ntry podue For & wh & 765 & 424 & 54193.7 & 100 & & 0 & 0 & 0 & & $\sqrt{5}$ & 0 & 965 & 18 \\
\hline Nity Traming far & 1021 & 1021 & 394 & $627 \cdot 38.6$ & 0 & & 0 & 0 & 0 & 0 & i) & 1 & 1021 & 8 \\
\hline Jad Rethatiblatation & 1100 & 988 & $28 j$ & 70528.6 & 112 & & .0 & 0 & 0 & 0 & 0 & 0 & 0 & 96 \\
\hline iucation. & 2282 & 2282 & 557 & 1725124.4 & 0 & & 282 & 0 & 0 & 0 & 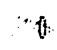 & $\theta$ & 0 & 0 \\
\hline aqhen scthos . & $700^{\circ}$ & 330 & 44 & $586 \quad 7.0$ & 70 & 0 & 0 & 0 & 0 & 0 & 0 & 0 & 0 & 630 \\
\hline HOU KELATED UFP & 615 & 615 & 546 & 69.88 .8 & 0 & 0 & 0 & 0 & 0 & 0 & 615 & 8 & 0 & 0 \\
\hline YAL HHA STHod & $4: 1$ & 451 & 313 & 13867.4 & 0 & 0. & 0 & ) & 0 & 0 & 0 & 1 & $i$ & 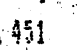 \\
\hline
\end{tabular}

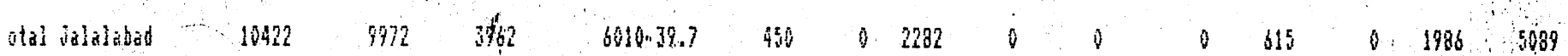
AZRR:

\begin{tabular}{|c|c|c|c|c|c|c|c|c|c|c|c|c|c|c|c|}
\hline ostruction & 514 & 874 & 243 & 22652.3 & 40 & & i & & 0 & 0 & 0 & & $\theta$ & 0 & 474 \\
\hline aeray Production & 640 & 350 & 137 & 41324.9 & 90 & & 0 & & 0 & 0 & 0 & & $6^{\circ}$ & 0 & 550 \\
\hline aro-nethad statioñ & 1010 & 850 & $3 i 1$ & 5277.8 & 168 & & 0 & & 0 & 0 & 0 & & 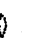 & 3 & 850 \\
\hline oc.Train for disabl & 1029 & 1028 & 291 & 73728.3 & 0 & 862 & 0 & & 0 & 0 & 1 & & 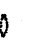 & 0 & 166 \\
\hline Ende Hoc. Thaning & 177 & 1377 & $\cdot \quad+305$ & $.1072 \quad 20.7$ & 0 & inII & 0 & & 0 & 0 & i) & & ) & 0 & 166 \\
\hline migation : & 1433 & $\begin{array}{r}284 \\
\end{array}$ & 359 & 915.28 .7 & 149 & 0 & 0 & & 0 & 0 & 0 & & 0 & 0 & 1284 \\
\hline jod Rehatisiation & 969 & $89 \%$ & 309 & 58034.8 & 30 & $\theta$ & 0 & & 0 & 0 & 0 & & 0 & 0 & 389 \\
\hline Q Ia dani fhori(2) & 2278 & 2178 & 1179 & 99954.1 & 100 & 0 & 0 & & $\therefore 0$ & 0 & 0 & & 0 & 2178 & 10 \\
\hline Ater Suppiates & $\begin{array}{r}1063 \\
0\end{array}$ & $\begin{array}{r}763: \\
0\end{array}$ & $458^{\prime \prime}$ & $\begin{array}{c}595.47 .6 \\
0.1\end{array}$ & 100 & 0 & 0 & & 0 & 0 & 0 & & 0 & 0 & 63 \\
\hline 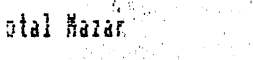 & 1020 & 9293 & $357 ?$ & 599637.5 & 727 & 2073 & 0 & 0 & 0 & 0 & $\vartheta$ & & $i$ & 2178 & \\
\hline 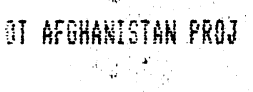 & 42,919 & 37,950 & 11,503 & $28,36729.0$ & 2,869 & 4,290 & 2,282 & 0 & 0 & 0 & 615 & & $\theta$ & 8,50 & 24,211 \\
\hline enaje jncoue Genat & 1825 & 1825 & $735:$ & 107040.3 & & & 0 & 0 & 1325 & 0 & 0 & & 0 & 0 & 500 \\
\hline ro.For Disatied & 2090 & 2090 & 896 & $1204: 42.4$ & 0 & 0 & 0 & 0 & 1490 & 0 & 0 & & 0 & $\therefore 0$ & 608 \\
\hline Eale Loan sthare & 611 & $611 \%$ & 307 & 30450.2 & 0 & 0 & 20 & 611 & 0 & 0 & 0 & & 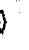 & 0 & \\
\hline
\end{tabular}

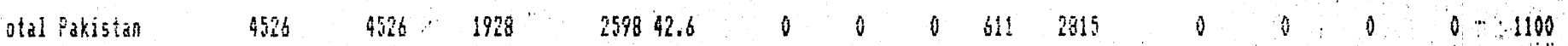

AHW THA

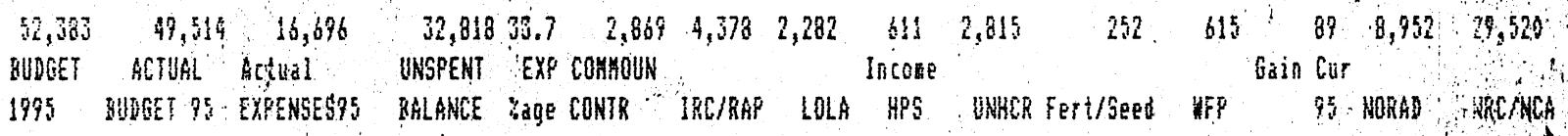

Total andual budget including share of afp cash of the drount of food provided by WF under food

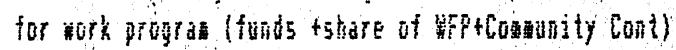

$18-i$

1) Project started in the end of 1994 . thy spent Rs=81614 of thier budget in that Year.Total expenses up to end on of June $9585=93319$ 2) Project started inthe end of 1999. thy 5 pent $\$ 5=16929$ of thier budget in that Year. Total expenses upto end of June $95,85=1196405$ 


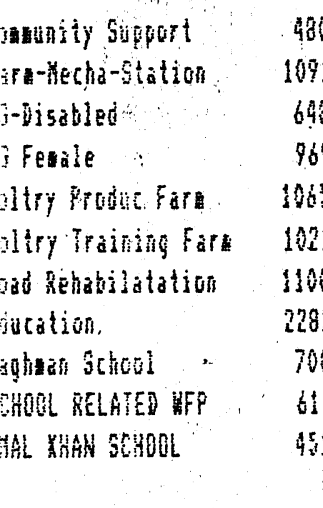

ital walabod $10422 \quad 972 \quad 36$
$27742.3 \quad 0$

$35761.3 \quad 168$

$414,36.3 \quad 0$

$57141.1 \cdots$

$54193.7 \quad 100$

$627.38 .6 \quad 0$

$70528.6 \quad 112$

$1725124.4 \quad 0$

$5967.0 \quad 70$

69.88 .8

138.69 .4

$\begin{array}{lll}0 & 0 & 0 \\ 0 & 0 & 0 \\ 0 & 0 & 0 \\ 0 & 0 & 0 \\ 0 & 0 & 0 \\ 0 & 0 & 0 \\ 0 & 0 & 0 \\ 0 & 0 & 0 \\ 0 & 0 & 0 \\ 0 & 315 & 0 \\ 0 & 0 & 0\end{array}$

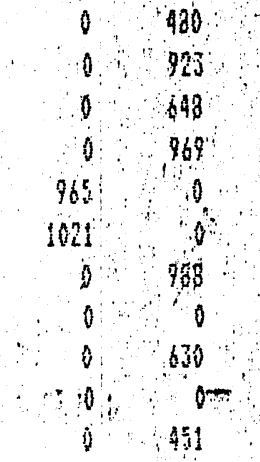

$\begin{array}{llll}0 & 1 & 0 \\ 0 & 0 & 0\end{array}$

AZAR:

striction

iergy frobution

\begin{tabular}{|c|c|c|}
\hline $53^{\frac{4}{4}}$ & $474 \ldots$ & 243 \\
\hline 65 & 50 & 137 \\
\hline 1018 & $80^{\circ}$ & 321 \\
\hline 1028 & 1028 & 271 \\
\hline 137 & $1377 \therefore$ & -295 \\
\hline 1433 & 1284 & 389 \\
\hline 969 & $38 \%$ & 309 \\
\hline 2778 & 2178 & 1179 \\
\hline 1033 & 765 & $49^{\prime}$ \\
\hline & $j$ & \\
\hline
\end{tabular}

$32652.3 \quad 40$

$41324.9 \quad 90$

$5277.8 \quad 168$

73728.3

(1) 362

.107220 .7

inil 0

$91528.7 \quad 14900$

$58034.8 \quad 30 \div 00$

315

1009

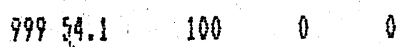

$305.47 .6 \quad 100$

0.

intal a

1030

59937.

$72073 \quad 0 \quad 0 \quad 0$

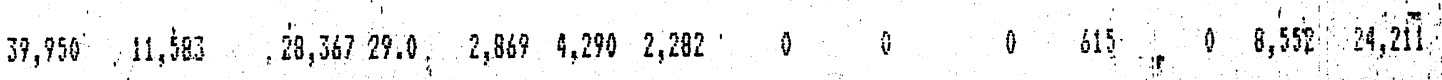

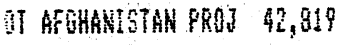

eade jicoue Genrat 1825

$1925 \quad 735 \quad 107040.3$

$2090 \quad 2090 \cdot 396$

1204.42 .4

611.5307

30450.2

1325

Enale Loun Schase

611

00000

$0 \quad 1 \quad 0$

$\begin{array}{lll} & 1 & \\ 0 & 0 & 474 \\ 0 & 0 & 550 \\ 0 & 0 & 950 \\ 0 & 0 & 166 \\ 0 & 0 & 166 \\ 0 & 0 & 1284 \\ 0 & 0 & 399 \\ 0 & 2178 & 0 \\ 0 & 0 & 963\end{array}$

otal Pakistan

$45 \%$

$4.26 \div \quad 1928$

259842.6

0003112815

$0 \quad 0: 0$

1. 1100

BAW TOTAL

$52,383 \quad 49,519, \quad 16,696$

$32,81833.7 \quad 2,869 \quad 4,378 \quad 2,282 \quad 641 \quad 2,815$

$252.615 \quad 878,752 \quad 7,520$ BUDGET ACTAL ACtual

UNSPENT EXY COHMOUN

Incone

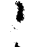

1995 MUOET 7 : EXENGES

Total andal budget including share of afp cash of the arount of food provided by whe under fool

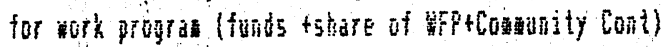

$18-i$

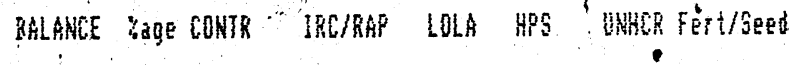

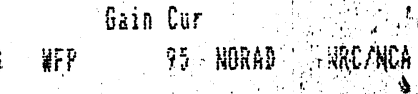

